\title{
Fekete Magdolna Beáta
}

\section{Egy útleírás filológiai tanulságai Aranka György jelentése erdélyi tudományos utazásáról}

\section{Bevezető}

Az irodalomtudomány mai állapotát nagymértékben jellemzi a kritikus módszertani reflexió, számos szakterület újrafogalmazta elveit, céljait, jó példa erre a régi szövegekhez való viszonyulás is, mely ma, a technika korszakában a tágabb olvasóközönségnek legfeljebb kuriózumnak számít, a kutatónak azonban csemege, és sok esetben számos értékes információval szolgál. Vita tárgyát képezheti, hogyan is közeledjünk egy régi, pár száz éves szöveghez, kézirathoz. Felvetődik a kérdés, miként kezelhető, milyen mértékben interpretálható, érdemes-e a szerzői intenció után kutatnunk, vagy - modern, hermeneutikai módszerrel - befogadóközpontú esztétika felöl kell megközelítenünk a szöveget. Itt idézném Karl Lachmann német filológust, aki - bár szövegközlésröl beszél - fontos aspektusát ragadja meg a szöveghez való viszonynak: „Feladatunk és szándékunk, hogy elegendő mennyiségủ jó kézirat segítségével az ezek alapját képezỏ szöveget bemutassuk, amely vagy maga az eredeti kézirat, vagy ahhoz közel kell állnia." ${ }^{, 78} \mathrm{Ez}$ a kijelentés két évszázad távlatából sem nevezhető avíttnak, a német medievisztika megteremtője ugyanis találóan határozza meg a szöveggel való bánásmód lényegét: minél eredetibb szöveget adni az olvasó kezébe. A régi szövegekhez való ilyenszerü viszonyulás érvényesül ma is. A német medievisztika területén már az 1970-es évek közepén megszületett az az elmélet, mely mára a szövegkiadás egyik alapját képezi. Eszerint a kutató a meglévő kéziratváltozatok alapján feltételezi az instabil szöveget (unfester Text), ám nem ez az egyedüli módszer. a szövegrekonstrukció gyakorlata ma a Lachmann-módszertöl a recenzió és emendáció útján elöállított szövegkritikai kiadásokon át a kéziratokban fennmaradt szövegek puszta lenyomatáig, átírásáig terjed, legfeljebb csak formálisan közremüködő kiadó bármiféle beavatkozása nélkül. ${ }^{79}$

Bár ezek a kijelentések föleg a középkori szövegekre vonatkoznak, érvényességüket kiterjeszthetjük a késỏbb keletkezett kéziratokra is. Láthatjuk, hogy a viszonyulás rendkívül heterogén, ezek a megközelítések nem zárják ki egymást. Az általam vizsgált kézirat Aranka György 1793-ban írott, székelyföldi gyưjtöútjáról való jelentésének másolata. A köztudatban Aranka szinte ismeretlen, az irodalomtörténet sem alkotott róla egységes, kiforrott képet. A tudományszervezöt, a Magyar Nyelvmívelö Társaság titoknokát értékeltẻk, a költőt, írót, fordítót aonban elmarasztalták: „Aranka alapjában véve dilettáns nyelvész és irodalmár, ő a patriarchális régi életformából nem szakadt ki." - mondja róla Enyedi Sándor. ${ }^{80}$

Helytelen és igazságtalan lenne Arankát ilyen sarkítva megítělni. Kevés a valószínüsége annak, hogy a könyvtárak még olyan szövegeket rejtegetnének, melyek nagy mértékben megváltoztatnák vagy átalakítanák az Aranka-kutatás már meglévő eredményeit, ezért szerencsésebb lenne a már meglévő Aranka portrét árnyalni.

\footnotetext{
${ }^{78}$ Lachmann, 1876.

${ }^{79}$ Schnell, 2000, 462-480.

${ }^{80}$ Enyedi 1988, 26.
} 


\subsection{Az utazó portréja}

Bemutatni, leírni egy személyt mindig több veszélyt is rejteget magában, egyfelöl a mitizálás, túlzás, másfelöl az évszámok lexikonszerü felsorolásának veszélyét. Ezért érdemes megnézni Takáts József Gyulai, emlékbeszéd, kanonizáció címü tanulmányát, ${ }^{81}$ melyben a szerző ilyen irányú elméletét fejti ki. Gyulai Pál emlékbeszédeit vizsgálva megállapitja, hogy: „Az egyének élete és teljesítményei, akikről Gyulai emlékbeszédei szólnak, a müfaj elbeszélésmódja alapján nem önmagukban állók és értelmezendők, hanem beletartoznak valami náluknál fontosabba (s értelmúket is ebben nyerik el): egy-egy közösség (testület vagy nemzet) vagy egy-egy eszme történetében."82 Ez önmagában nem elvetendő megközelítés, hiszen a bemutatott személyt saját korának viszonyai között láttatni helyénvaló dolog. A tanulmány következö részében sorolja fel Takáts azokat a retorikai formákat, beszédmódokat, melyek idealizálják a személyt: a beszéd tárgya mindig egy szép élet, nagyon fontos a halál pillanatának, módjának kiemelése, csak azokat az elemeket kell beemelni az életrajzból, amelyeket a beszéd szerkezete megbír, és melyek meghatározott eszméket és viselkedésmódokat szemléltetnek. ${ }^{83}$ A most következő portré célja nem a kultuszteremtés, lehetőleg tárgyilagosan szeretném bemutatni Aranka életútját, tevékenységét, viszonyait.

A protestáns családból származó Aranka iskoláit Marosvásárhelyen, majd a jogot és bölcseletet Nagyszebenben végezte. 1764-től írnok a marosvásárhelyi királyi tábla elnökének irodájában. 1787-től törvényszéki bíró, 1796-tól táblai ülnök. Munkássága többirányú, már az 1780-as években jelentek meg versi a Magyar Hírmondóban, a Magyar Muzeumban és az Orpheusban. Belekezdett Shakespeare fordításába is, ezen kívül emlitésre méltó még az Anglus és magyar igazgatásnak egybevetése (Kolozsvár, 1790), Újmódi gonosztevõ címü öt felvonásos színjátéka, melyet franciából dolgozott át, Apró munkái (Marosvásárhely, 1805), amely filozófiai elmélkedésket tartalmaz, és Elme játékai (Nagyvárad, 1806) címü verseskötete. Nem szeretném esztétikai és poétikai szempontból értékelni a munkákat, mivel elsődlges célom az ismertetés. Aranka tevékenységének sokféleségét, szakmai mozgásterének lehetőségeit szeretném példázni a következő résszel Jakab Elek tanulmányából:

„... a székely határôr katonaság felállitása ügyében tollvívõ volt. 1782: a Torda vármegyei föbiró Geréb József zsarolási ügyében nyomozó biztos. 1785: a borgói oláh határörök és a gróf Bethlen nemzetség között egyenetlenség és adóhátralék iránt folyt perben szintén, 1788. április 3-án a marosi ev. Református esperesi köri zsinaton a kormányt, mint annak teljhatalmú biztosa képviselte. 1791-ben az országgyülési jegyzōkönyvek tisztázására, összeolvasására és végleges megvizsgálására hivatali rangjukhoz mért napidijjal négy egyén neveztetett ki: egyik Aranka volt. 1803-ban egyházi törvénytelen esketés kérdésében is volt biztossá kinevezve." 84

Egy másik tevékenységi területe Arankának tudományszervezői munkássága: 1791ben írta meg Az erdélyi magyar nyelvmiveló társaság felállitásáról való rajzolat a haza felséges rendihez és $A z$ erdélyi kézírásban levố történetiróknak kiadására felállitandó társaságnak rajzolattya címủ munkáit, mindkét munka Kolozsváron jelent meg. Ez a

\footnotetext{
${ }^{81}$ Takáts (szerk.), 2000, 163-174.

${ }^{82}$ I.m.: 164.

${ }^{83}$ Lásd bỏvebben: i.m. 165-169.

84 Jakab. 1884, 7.
} 
törekvése nem volt újdonság Erdélyben, a XVII-XVIII-dik század folyamán számos próbálkozás létezett egy tudós társaság felállítására, dolgozatomban később részletesebben visszatérek ezekre. A két társaság programtervezetéből tudomást szerezhetünk Aranka jó szervezökészségéröl, kiváló diplomáciai érzékéröl - néha ugyanis nagyfokú körültekintésröl és óvatosságról tesz tanúbizonyságot -. valamint felvilágosult eszméiröl a nyelvet, müvészetet, tudományokat illetően.

Az Erdélyi Magyar Nyelvmívelő Társaságról írt rajzolatot a várható költségek bemutatásával kezdi, ${ }^{85}$ azután tér rá a társaság munkálkodásainak tárgyára, amely magába foglalja a nyelvészeti, irodalmi, néprajzi, földrajzi és biológiai ismeretek összegyüjtését, rendszerezését és terjesztését. Ezek a területek ugyanakkor Aranka érdeklödési köreit is fedik: ő maga is ír irodalmat, van saját okirat-gyüiteménye valamint kőzetgyüjteménye. Hogy mindezen terveit megvalósítsa, széleskörü levelezést folytatott a kor tudósaival, irodalmáraival, hogy csak egy párat említsünk: Benkő József, Teleki Sámuel, Kazinczy Ferenc, Csokonai Vitéz Mihály, Gvadányi József és Fekete János. Egyesekhez nemcsak a tudósi, szervezési érdek, hanem szoros barátság is füzte, például Telekihez, Benkőhöz, sőt Feketéhez is. Aranka mint a társaság titoknoka kezében tartotta a Nyelvmívelö Társaság teljes ügyintézését, családot nem alapított, egész életét a két társaságnak szentelhette, szervezömunkája és lelkesedése tartotta össze a Társaságot. Miután 1798-ban lemondott állásáról, a Társaság is megsínylette távozását. ${ }^{86}$

A tudományszervező titoknok képébe jól beleillik az utazó Aranka portréja is. Az utazásról mint korjelenségröl a későbbiekben bövebben beszélek.

\subsection{A kézirat lelöhelye}

Dolgozatom témája Aranka Györgynek elsö, 1793-as székelyföldi utazásáról írt jelentése. A jelentés kéziratos szövege egy kolligátum ${ }^{87}$ része, a Magyar Tudományos Akadémia Könyvtárának Kézirattár és Régikőnyv gyủjteményében, Magyar Irodalom Régi és új írók 7-es jelzet alatt, a 11. laptól a 17. lapig terjedő részben. A szöveg nem Aranka György keze írása, a kéziratot az Erdélyi Nyelvmívelő Tảrsaság irományaiból másolta Vass József felügyelete alatt Mák Ferenc, a kolozsvári római katolikus gimnázium nyolcadik osztályos tanulója. Egy pár szóban írnẻk arról, hogyan is került a Magyar Akadémia könyvtárába ez a jelentés. Már maga Aranka is lajstromot vezetett külön a Nyelvmivelö Társaság és külön a saját iratairól és leveleiröl, végrendeletében külön kezelte az iratokat, néhány könyvet el is adott magángyűjtőknek. ${ }^{88}$ Nem sokkal a Társaság megszủnése után megkezdödött a gyüjtemény szétszóródása. Döbrentei Gábor veti fel elsőnek a Társaság felújításának eszméjét, 1818-ban az alakuló Tudós Társaság első ülésén bizottságot neveznek ki a Nyelvmívelő Társaság iratainak összegyűjtésére. Mivel legfelsőbb jóváhagyás hỉján az új társasảg nem müködhetett, Döbrentei távozott Erdélyböl.

A kéziratok a kolozsvári református kollégiumba kerültek, itt talált rảjuk Vass József, igy másolhatta le Mák Ferenc az általam vizsgált jelentést. A jelentés a Kéziratkiadó Társasághoz íródott, azonban a két társaság tevékenysége nem határolható el élesen egymástól, így az iratok is a Nyelvmívelő Társaság gyűjteményeibe kerültek. A XIX. század

\footnotetext{
${ }^{85}$ Aranka György, $1791 \mathrm{~b}, 5$.

${ }^{86}$ Enyedi, 1988, 38.

${ }^{87}$ A kolligátum tartalma: Péteri Takács József: A hazai utazásról. Aranka György Jelentése székelyföldi tudományos utazásáról, A gyulafehérvári csillagda leírása, Kovács Lôrinc Pál: Az abrudbányai fakönyvröl, Koprziva Ferenc: Jelentés Erdély néhány régiségéröl, Gyarmati Sámuel: Rövid jegyzések a régi és ujabb magyar grammatikákról

${ }^{88}$ V.ö. Egyed, 2000c, 138-139
} 
második felében az iratok az Erdélyi Múzeum birtokába kerültek, majd a politikai változásokból is következően szétszóródtak magyarországi és erdélyi könyvtárakban. ${ }^{89}$

Az Aranka-kutatás figyelmét elkerülte ez a szöveg. Vass József közölte ${ }^{90} 1854$-ben az Új Magyar Muzeum májusi füzetében. Jakab Elek 1884-es tanulmányában felsorolja az utazás állomásait és számba veszi, hány kéziratot talált Aranka, ${ }^{91}$ azonban bövebben nem tárgyalja az utazás eseményét. Jancsó Elemér 1955-ös munkájában ${ }^{92}$ csak utal arra, hogy Aranka kétszer járt Székelyföldőn gyüjtöúton, de nem fejti ki bövebben az utazás körülményeit. F. Csanak Dóra tanulmánya ${ }^{93}$ a Kéziratkiadó Társaság megalakulásának körülményeire fekteti a hangsúlyt és csak egy mondat erejéig említi Aranka székelyfôldi útját, szerinte az utazás egyik célja a pártfogók toborzása volt. Enyedi Sándor sem tér ki a székelyföldi utazásokra, bár a társaság gyüjtőmunkáját értékelii. ${ }^{94}$

\subsection{A kutatás célja}

Kutatásom célja a kézirat szövegének feltárása - filológiai vizsgálata - és közlése, ezáltal az Aranka-szövegkorpusz bővitése, a jelentés elhelyezése a dokumentáris értékü szövegek és az irodalmi prózaszövegek sorában. A kéziratot először tartalmi szempontból vizsgálom meg. Szeretném megnézni, mit tart fontosnak egy XVIII. század végi, tudományos céllal utazó értelmiségi. További célom a kézirat és a Vass József által 1854ben publikált szövegváltozat egybevetése.

Mák Ferenc Vass József felügyelete alatt másolta a szöveget, közölte az eredetét, Vass József azonban nem közli a forrást, söt más címmel és számos változtatással teszi közzé a jelentést. Ezután a müfajiság szempontjából vizsgálom a szöveget. Aranka jelentést irt egy utazásról, ezért érdekes a szöveget az okirat-irodalom és az utazási irodalom felöl is megközeliteni.

Végül összehasonlitom a kéziratban felsorolt célokat a Kéziratkiadó és Nyelmivelö Társaság létrehozásáról szóló programtervezetekkel. Aranka az előbbi megbizásából utazott. még a Nyelmívelỏ Társaság megalakulása elött azonban már 1791-ben elkészitette mindkét tervezetet, ezért érdemes vizsgálni a szövegnek mindkẻt tảrsasảghoz való viszonyát. A két társaság munkássága végül is egybefonódott: 1796-ban a Nyelvmivelỏ Társaság adta ki antológia formájában a beérkezett munkákat, ebben közölte Aranka az 1793-ban talált munkák cimeit is. ${ }^{95}$

A feltáráshoz Aranka mủvei esetén az eredeti szövegeket használtam. ${ }^{96}$

\subsection{A feltárás módszerei}

A szövegfeltárás elsỏdlegesen filológiai tevékenység, azonban számos más, olyan tudományos területtel is kapcsolatba hozható, melynek tárgyát a szöveg képezi: a textológia, grammatika, történetírás, irodalomtörténet, irodalomelmélet. Egy kézirat feltảrása pedig egészen sajátos kutatási és megfigyelési pontokat nyủjt, és teljesen más megkőzelitést kiván.

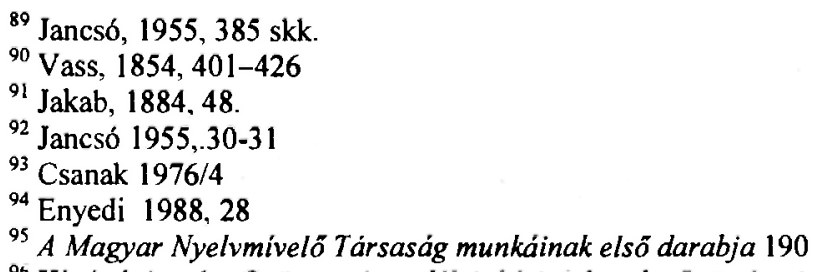

${ }^{96}$ Kivétel Aranka György: Az erdélyi, kézirásban levô történetirók kiadására Jelállitandó társaságnak Rajzolattja. 
A kéziratkiadás is a filológia keretébe tartozik, szorosan összefügg a szövegfeltárással. A kéziratok kiadását illetően a francia Pierre Marc de Biasi elmélete figyelemre méltó ${ }^{97}$ Biasi kétféle szövegkiadást különböztet meg: horizontálisat és verikálisat; az elöbbi a szöveggenézis egy fázisát dolgozza fel, az utóbbi a keletkezéstörténet egészét térképezi fel. Mindkét esetben „a módszer ösztönöz a vázlatok minél teljesebb feltárására, ennek háttértevékenységeként a más-más közgyüjteményekben örzött dokumentumok feldolgozására és egyesitésére, a feljegyzések, vázlatok, töredékek eddigi periférikus helyének a megváltoztatására, beemelésére az alkotó folyamatba. ${ }^{198}$ Ezt a gondolatot azért tartom fontosnak, mert az általam vizsgált kézirat - bár teljes szöveg - mégis perifériára szorult az Aranka-életmüben. Újraértékelése, vizsgálata más perspektívát nyủjthat a már meglévö Aranka-képröl, a táblabiró, titoknak, író és költö mellett az utazỏ Aranka is megérdemli a figyelmet.

A két kiadástipus közül dolgozatomhoz a horizontális kiadás elmélete áll közelebb. Biasi szerint ennek célja egy olyan kézirat(együttes) megjelentetése, amely a genézis egy adott mozzanatát, vagyis az író munkájának egy meghatározott fázisát rajzolja elénk. Ez a dokumentum-együttes lehet egy olyan dosszié része, amelyböl nem született vẻgleges szöveg, de származhat egy befejezett vagy befejezetlen, kiadott vagy kiadatlan mủ genetikus kézirattornyából is. ${ }^{99}$ Akár egyetlen dokumentumot, akár vaskos kéziratköteget foglaljon magába, a horizontális kiadást alapvetöen az különbözteti meg a vertikảlistól, hogy nem az irásfolyamat egészét kívánja megjelentetni, hanem e folyamat egyetlen mozzanatát rekonstruálja. ${ }^{100} \mathrm{~A}$ horizontális kiadás egy adott genetikus dosszié keretén belül nem törekszik a szekvenciás jellegü, csak más dokumentumokkal együtt értelmezhetö diakrón kézirat-együttesek feldolgozására: a mü „piszkozatai ", vagyis azok az írásrétegek, amelyek csak az egymáshoz kapcsolódás sorrendjében és a folyamat egésze szempontjából értelmezhetöek, természetesen a vertikális kiadás hatảskörébe tartoznak. ${ }^{101}$

A szövegfeltárás esetén vita tárgyát képezheti, hogy milyen szempontokból kell/lehet vizsgálni a szöveget, mennyire jelent elemzést, értelmezést vagy kommentárt ez a tevékenység. Ebben a tekintetben helyénvalónak találom Wolfgang Pross kijelentését:

„A szöveg olvasója rendszerint azt kivánja a közreadótól, hogy legyen segítségére az olvasásban - magyarázzon meg bizonyos szavakat, fogalmakat, utalásokat. Két problématerület megvilágitását várja tehát, amihez egyrészt bizonyos történetilexikális tudást kell rendelkezésére bocsátania, másrészt biográfiailag és történetileg kell kommentálnia a szöveget, hogy ezáltal áthidalható legyen a mindenkori szövegtôl való távolság, mely a nyelvi jelentés változásában és a privát-illetve kollektiv történeti anyag referenciájának idegenségében fejezödik ki. Igy elkerülhetö, hogy az olvasást a megértésnek ellenálló pontok zavarják meg. ${ }^{\prime \prime 02}$

\footnotetext{
${ }^{97}$ Biazi, 1998 414-434.

${ }^{98}$ Kerényi 1998/4, 411, kiemelés. F.B.

99 Biasi, 1998, 427. Biasi a "genetikus kézirattorony" szókapcsolattal példázza érzékletesen a horizontális és vertikális kiadás közti különbséget. Szerinte egy szöveg különböző̉ verziói, kéziratai, piszkozatai a keletkezés sorrendjében egymásra helyezve egy kézirattornyot alkotnak. Ha ebből egy szövegvariánst veszünk ki, a tornyot vízszintesen vágva ketté, és vizsgálunk, akkor horizontális kiadásról beszélhetünk, ha meg az összes dokumentumot keletkezési sorrendben közelítjük meg, a tornyot függölegesen vizsgálva, akkor vertikálisról.

${ }^{100} \mathrm{Uo}_{0}$

${ }^{101}$ Uo.

${ }^{102}$ Pross. 2000, 542.
} 
Megpróbálok eleget tenni a Pross által felsorolt kitételeknek azáltal, hogy a kézirat szövegében megjelenő neveket névmagyarázatban közlöm, a szövegben az esetleges szövegjavításokat, betoldást, törlést lábjegyzetben jelzem, oly módon szeretném megközelíteni a szöveget, amely közvetlenül szövegértelmezést, formai, tartalmi és müfaji vizsgálatot jelent.

Módszertani kérdés az is, hogy miként kezelünk egy olyan szöveget, amely nem a szerző kézirásában maradt fenn. Aranka jelentését 1852-ben, tehát majd hatvan évvel a keletkezése után másolta le Mák Ferenc. Stephen G. Nichols így jellemzi a másolás tevékenységét:

„A kéziratmásolás látszólag sima mủvelete sem mentes a mimetikus beavatkozástól. A másolás során az irnok az eredeti költỏ helyébe lép, sokszor változtatja a szavakat, vagy éppen a narrativ rendet, bizonyos részeket tömörit, vagy lerövidit, miközben más helyekre új anyagot illeszt be. Ahogy a képi változtatások, úgy az irnoki átdolgozás is lehet az eredeti mü létrejötte és a másolatok elkészitése közötti idöben kialakult esztétikai izlésváltozás következménye". ${ }^{103}$

Aranka György jelentésének esetén egy okirattal van dolgunk, amely elsődlegesen tényeket közöl, esztétikai értéke csak másodlagos. A másoló nyolcadik osztályos gimnáziumi tanuló, tehát nem jelenthetjük ki, hogy a másolás egy „fejlettebb értékelést" képezne, ahogy azt Nichols feltételezi. ${ }^{104}$ Találunk a szövegben olyan elemeket, melyek nyilvánvalóan másolásból eredő szövegromlások - ilyen például a címek kisbetủvel való írása. Mivel csak a Mák Ferenc által másolt verzió és a két évvel később megjelent változat állt rendelkezésemre, a két szövegben elöforduló eltéréseket vizsgáltam. Valószinŭ az is, hogy Vass József az eredeti iratot használta a kiadás alapjául, azonban ezt kevésbé tartom fontosnak, a vizsgálat tárgya ugyanis a Mák Ferenc által másolt kézirat.

\subsection{Irodalom- és tudományszervezés a XVIII. századi Magyarországon}

Aranka igyekezete egy tudós társaság felállítására nem volt egyedülảlló és új törekvés. Röviden számba szeretném venni azokat a tudós társaságokat és próbálkozásokat, melyek a Kéziratkiadó Társaság és Nyelvmivelő Társaság megalakulásához vezettek. Európában már a reneszánsz idején csoportosultak a tudósok közös munkára, kutatásra és sok esetben sikerült egy-egy fejedelmi mecénás anyagi támogatását is megszerezniük. A XVIII. században pedig már nemzeti programmal (nyelvápolás, honismeret) alakultak társaságok. Német területen Gottsched vezetésével mủködött 1727-töl a Deutsche Gesellschaft nevet viselö lipcsei poétikai társaság, a franciáknál 1635-ben már rendeletben hagyta jóvá a király a tudós társaság müködését. Angliában 1660-tól müködött a Royal Society, szintén uralkodói támogatással.

A külföldi lapokban és közvéleményben a magyarok hosszú ideig tudatlan ès müveletlen népként szerepeltek, bár számos magyar tudós közölt cikket főleg németországi lapokban: Köleséri Sámuel, Raymann János, Buzinkay György, Bél Mátyás. ${ }^{105}$ Kosáry Domokos szerint az 1700-as évek első felében évente mintegy 35-40 diák ment külföldre tanulni, ${ }^{106}$ föleg protestánsok. A katolikus felekezetü ifjak elött belföldön is nyitott volt a

\footnotetext{
${ }^{103}$ Nichols, $2000,489$.

${ }^{104}$ Uo.

${ }^{105}$ Lásd bővebben: Szelestei, 1989, 14.

${ }^{106}$ Kosáry, 1980, 128.
} 
pálya a továbbtanulásra, képzésre. A fokozatosan kialakuló értelmiségi réteg számára azonban még nagyon kevés volt a lehetőség, hogy a tudományok vagy mủvészetek terén kutathassanak, dolgozhassanak. Általában valamely förangú nemes, néha maga az uralkodó támogatta a tudósokat. Ezek késöbb egy-egy jelentös személy köré csoportosulva alakítottak társaságot. Az elnevezés kérdése nem mindig merült fel, egyes esetekben academia, gelehrte Gesellschaft vagy a societas nevet viselték. A XVII. századi próbálkozások közül elsök a jezsuita történeti forrásgyüjtö iskolák, ezen belül Inchofer Menyhért, Telekesi István neve emlitendö meg. A tudományos történeti forráskutatás megalapitójának Hevenesi Gábort tartja a szakirodalom, ${ }^{107} \mathrm{o}$ szerkesztette meg a magyar tudományos történetírás alapító okmányának tekinthetö írását, amely csak kéziratban maradt fenn, címe: Modus materiae. Ezzel párhuzamos a protestảns egyháztörténet-írás, ezen belül Pápai Páriz Ferenc, Debreceni Ember Pál valamint idős és ifjabb Burius Jảnos munkássága említendö meg.

A 18. század elsö felében már körvonalazottabb a tudományszervezés. Bél Mátyás 1713-ban adta ki tervezetét a magyar nyelv történetéröl, amelyben ilyen célkitüzések szerepeltek: magyar nyelvü Biblia-forditások, szótárak készítése, a magyar költészet történetének megírása. Bél felkéri honfitársait az együttes munkára, a tudós világ elé való kilépésre. Késöbb, 1718-ban újra sürgette az együttmüködést, mivel úgy érezte, elözö felhívása eredménytelen maradt. Levélben kérte a vidéki papoktól, tanítóktól, tisztviselöktöl a vidékükre vonatkozó információkat: elhelyezkedést, határokat, címerek magyarázatát, földrajzi és biológiai adatokat, az ott élö föúri és nemesi családok genealógiajját, az ott lévö intézmények és minden különös dolog leírását. Figyelemre méltó a hasonlóság a Nyelvmívelő Társaság tervezetének Honismeret címủ fejezetével. Bél Mátyás 1720-tól már királyi engedéllyel és támogatással folytathatott kutatómunkát. 1721-ben alapitotta az elsö rendszeresen megjelenö magyarországi folyóiratot, a Nova Posoniensiát, amelyben többször felvetette egy tudós társaság alapításának gondolatát. A társaság célja a közhaszon elömozdítása lett volna: irodalomtörténet, jogi és fizikai-gazdasági osztályok felállitását javasolta. Az elnök feladata a tagok meghivása a társaságba, $s$ ott dolgozatok készitésére való buzdítás, aztán pedig a dolgozatok cenzúrázása és kinyomtatása. E munkában segíti egy titkár: ö gyüjti össze a cikkeket, ügyel a nyomdai munkákra, s levelezéssel tartja fenn a kapcsolatot a távollevő tagokkal. A Pozsonyban élö tagok az elnök felügyelete alatt havonként kötelesek összegyülni, mindhárom osztály havi közleményt tesz közzé Observationes Posonienses címmel. Ez a tervezet az uralkodó elé került, de nem részesült kedvező elbírálásban. Később Mária Terézia sem támogatta a kezdeményezést.

Bél Mátyással egyidőben próbálkozott Fischer Dániel, Szepes megyei orvos egy folyóirat megjelentetésével, amelyben természettudományi, kémiai, matematikai közlemények kaptak volna helyet. Évi két kötet kiadását tervezte, két rajnai forint elöfizetési dijjal, azonban a folyóirat nem jelent meg. Ezután néhány magánpróbálkozásról tudunk: az 1750-es években alakult egy pozsonyi társaság. A tagok, mindenféle formaságok nélkül, felolvasták egymásnak munkáikat. E társaság tagjai között találjuk Karl Gottlieb Windischt, Kempelen Farkast, Kastenholz Vilmost, Skolanics Józsefet és Kern Jánost. Később egy tervezet kidolgozására is gondoltak, támogatót szerettek volna, hogy mủveiket kiadhassák, könyvtárat és gyüléstermet tarthassanak fenn. Bár a társaság statútumát nem hagyták jóvá, ez volt az elsỏ olyan tudós társaság, amely nemcsak tervezetet dolgozott ki, hanem müködött is. ${ }^{108} 1763$-ban indult meg Bẻcsben Kollár Ádám magánkezdeményezése. A bécsi császári könyvtár őre elöbb csak levélben küldte el javaslatát Bányai István sárospataki és Sinai Miklós debreceni tanároknak. A társaság szabályai a következök lettek volna: minden rendü és vallású magyarországi személy tag lehet, bár a tagok száma tizenkettőre

${ }^{107}$ Szelestei, 1989.,44.

${ }^{108}$ I.m.: 83-84. 
korlátozott; ki-ki azt a területet müvelheti, amelyiket akarja; a tagok havonta leírják megfigyeléseiket és felfelfedezéseiket, postán elküldik társaiknak; a társaság elnökét és titkárát szavazattöbbséggel élethossziglan választják; az arra érdemes dolgozatokat meg kell jelentetni. Mivel a szétküldött levelekre kevés helyeslő válasz érkezett, ez a kezdeményezés is kudarcba fulladt.

A tudományszervezés másik formája volt a folyóirat-alapítás, jó példa erre a pozsonyi Landerer Mihály és Karl Gottlieb Windisch szerkesztette Pressburger Zeitung, amely 1764ben jelent meg, vagy a Bécsben 1771-1776 között kiadott Anzeigen aus sämtlichen kaiserlichen königlichen Erblandern, amelyet Tersztyánszky Dániel szerkesztett. ${ }^{109}$ Számos író és tudós tömörült a folyóiratok köré, és sokan vidékről kủldték cikkeiket. ${ }^{110}$

Bécs 1765 után fokozatosan törekedett arra, hogy Magyarországot beépitse a monarchia gazdasági és politikai rendszerébe, ennek érdekében adott ki 1768-ban Mária Terézia egy olyan rendeletet, amely gazdasági egyesủlések létrehozását szorgalmazta. A több helyen megalakult társaságok a gazdasági haszon és ismeretterjesztő mủvek közzétételén kívül azért is fontosak voltak, mert megszervezésük és részben feladatuk is megegyezett a tudós társaságokéval. Az 1770-es évek közoktatási reformjai során merỉlt fel egy bécsi tudományos akadémia alapitásának gondolata. A besztercebányai Hell Miksa dolgozta ki ennek tervezetét, de csak a természettudományok számára tervezett akadémiảt, úgy vélte, a teológia, az irodalomtudomány számára külön akadémiára van szülkség. Támogatónak az uralkodót szerette volna megnyerni, a tagok kétharmados szavazattöbbséggel jutottak volna az akadémiába. Anyagi alapként a monarchiában nyomtatott kalendáriumok jövedelmének e célra fordítását javasolta, azonban kiderült, hogy a kalendáriumokból származó jövedelem felét a kincstári illeték vitte el. A királynő végủl elvetette az akadémia tervét.

AZ 1780-as években egyre fontosabbá vált a nemzeti nyelv kérdẻse, főleg II. József nyelvrendelete után tette magáévá a köznemesség a nyelvmüvelés ügyét, amely szorosan összefüggött politikai kérdésekkel is.

A Bél Mátyás óta folyamatos kísérletek közé sorolhatjuk Batthyány Ignác püspök kísérletét, Batthyány nagyra értékelte Bél tevékenységét. 1786-ban írt tervezete szerint két társaságot szeretett volna felállítani: Az egyik csak egyházi személyekbỏl állt volna, az egyháztörténet müvelésére, a másik a magyar történelem mủvelésével foglalkozott volna. Martinovics Ignác is említi 1790. május 7-én Tertina Mihálynak írt levelében a magyarországi tudós társaság megalapításának szükségességét, szerinte az egyetem tanárainak meggyőzésével lehetne ezt elérni. ${ }^{11}$

Mindezek a kísérletek közvetetten előzménynek tekinthetők a Nyelvmívelö Társaság alakításához, közvetlenül hatottak Arankára a két tervezet megírásakor Bessenyei György és Báróczi Sándor valamint Decsy Sámuel röpiratai. A következőkben részletesebben beszélnék az Aranka által alapított két társaságpkról, létrejöttükrỏl, célkitủzésükrỏl, munkásságukról.

\subsection{Aranka György tudós társaságai}

Első tervezetét, A magyar nyelvmivelö társaság rajzolattyát Aranka 1790-ben az országgyülés alkalmával mutatta be a kormányzónak, és már 1791. január 2-án nyomtatott példányban is olvasható volt. A röpirat hamarosan közbeszéd tárgya lett, ezért Áranka kidolgozta másik tervezetét is: Az erdélyi kéziratban lévỏ történetírók kiadására felállítandó

\footnotetext{
${ }^{109}$ Kókay. 1979, 56-62.

${ }^{110}$ Például az Anzeigenben írt Czirbesz János. Perliczi János, Weszprémi István, Csapó József.

${ }^{111}$ Kókay, 1956, 58-60.
} 
társaságnak Rajzolattya címmel. Az előbbi társaság célja a nyelvmüvelés, mindenfajta tudomány nemzeti nyelven való mủvelése, múzeum létesítése, magyar nyelvtan megírása, tájszavak gyüjtése és régi szavak felelevenítése, színház létesítése; az utóbbié a történelmi tárgyú müvek, kéziratok összegyüjtése és kiadása volt. A Kéziratkiadó Társaság már 1791ben megalakult, de a munka csak 1792-ben, a második gyüléssel kezdődött.

Sajnos, a Kéziratkiadó Társaságra vonatkozóan nagyon kevés dokumentum maradt fenn, ezek kőzul egyik az általam vizsgált 1793-as jelentés Aranka elsỏ gyüjtőútjáról. A Nyelvmívelö Társaság iránt nagyobb volt az érdeklödés, 1793-ban egyre többen sürgették a társaság megalakulását, azonban a felsỏbb jóváhagyás késett. Enyedi Sándor szerint „Bảnffy György kormányzó és Aranka György találják meg a modus vivendit", ${ }^{112}$ egy próbatársaság felállítását. A Társaság 1793. december 3-án tartotta alakuló ülését, elnőkẻnek Bảnffy Györgyöt tekintette, aki a marosvásárhelyi gyüléseken általában nem vehetett részt, ezért az ülések pontos jegyzőkönyveit mindig elküldték neki. A Társaság titoknoka Aranka György volt.

A Kéziratkiadó és Nyelvmivelö Társaság munkássága a késỏbbiekben nem határolható el élesen egymástól. Az utóbbi által 1796-ban kiadott Próbamunkák $k^{113}$ olyan szövegeket tartalmaz, melyeket az elöbbi számára gyüjtött Aranka.

A továbbiakban a Nyelvmívelö Társaság tevékenységéröl beszélnék, melynek munkásságát Enyedi Sándor három korszakra osztja ${ }^{114}$. Az első periódus 1793-tól 1796-ig tart, Aranka már egy évvel az alakulás után változtatásokat foganatosít és a helybeli szellemi elitböl egy munkás társaságot alakít. A kiterjedt levelezésnek köszőnhetően pezsgó munka kezdődik, ám 1794-ben megkezdődött a Martinovics-féle összeesküvés leleplezése és megtorlása. A Nyelvmivelö Társaságot is elnémítják és 1795-ben csak két gyülést tarthatnak. Végül 1796-ban megjelenhetett a Próbamunkảk, mely lezárta a munkásság ezen szakaszát. Ebben a periódusban föleg a nyelvmüvelés játszott fontos szerepet a társaság tevékenységében.

A második szakasz 1796-1801 közé tehetö, ekkor fokozatosan elỏtérbe kerülnek a társadalomtudományok. A válságos szakasz után átmentik azt, amit lehet: a racionalizmus, deizmus, enciklopédikus jelleg azok az értékek, amelyeket meg lehetett jeleníteni. Mivel számos területről érkeztek be munkák, szükséges lett volna a szakosodás, a tudományos eredmények közzététele, ez azonban nem volt lehetséges. Aranka 1798-ban lemondott a titoknokságról, Jancsó Elemér szerint ez személyi és elvi ellentétekre vezethetỏ vissza. ${ }^{115} \mathrm{Ez}$ a tény dolgozatom szempontjából kevésbé releváns, fontos azonban, hogy a társaság megsínylette Aranka kiválását, $\mathrm{s}$ bár ö 1801-től újra titoknok lett, már nem tudott megbirkózni a feladatokkal.

Az 1801-1806-os periódust a válsảgok éveiként említi a szakirodalom. ${ }^{116}$ Ekkor föleg természettudományokkal foglalkoztak, megcsappant a társaság irảnti érdeklỏdés, kedvezőtlenek voltak a politikai, társadalmi feltételek is. A társaság kisebb megszakításokkal tizenhárom évig müködött, tehát a leghosszabb életü ilyen jellegü intézmény volt. Munkásságának sokrẻtüsẻgét föleg Jancsó Elemér fejtette ki: ezen belül megkulönbözetett nyelvészeti, történelmi, tudománynépszerüsitö, szépirodalmi, néprajzi tevékenységet. ${ }^{17}$ Magával az útleírás müfajával, mely egyaránt tartozhat a szépírói, tơrténeti, de akár a honismereti vagy tudománynépszerüsítő tevékenységhez, nem

\footnotetext{
${ }^{112}$ Enyedi, 1988, 20.

${ }^{113}$ A Társaság kiadványa eredetileg A magyar nyelvmivelö Társaság munkáinak elsó darabja címmel jelent meg.

${ }_{114}^{14}$ Vo. Jancsó 1955. 27.

115 Jancsó, 1955. 71.

${ }^{116}$ Enyedi, 1988, 37.

117 Jancsó, 1955, 47-70.
} 
találkozunk konkrétan - programszerüen megfogalmazva - a társaságok tervezetében. A Nyelvmívelő Társaság gyưléseinek jegyzőkönyveiben azonban több helyen találunk utalást arra, hogy számon tartottak egy-egy útleírás-kiadást, söt a gyüléseken be is mutatták. 1795 . november 8-án egy alsó-magyarországi, egy felső-magyarországi és két erdélyi útleírásról történik jelentés és

$$
\text { „a titoknok által úgy találtatott, hogy kiadása érdemes" }{ }^{118} \text {. }
$$

Ugyanezen év december 28-án ifjú Teleki Domokos, aki három útleírás szerzője, jelenti, hogy saját költségén adja ki útleírásait Bécsben. ${ }^{19}$ 1798. május 2-án Aranka bemutatja Péteri Takáts József munkáját: Hogyan kell utazni címmel. ${ }^{120}$ Ez utóbbi munka azért is érdekes, mert kézirata az általam vizsgált kézirattal egybekötve található a Magyar Tudományos Akadémia könyvtárában. Ezt a szöveget is Mák Ferenc másolta a Nyelvmívelö Társaság irataiból, szintén 1852-ben. A hat lapnyi terjedelmü szöveg egyféle elmélete az utazásnak, használati utasítás, kézikönyv szeretne lenni, alcímei a következök:

A hazai utazásról.

A hazai utazásból származó haszon.

Az utazásra megkívántató elökészületek.

Mely tárgyakra kell figyelni leginkább az utazónak.

Az útban történhetö bajok elkerülésére szolgáló észrevételek.

Mindez azt bizonyítja, hogy a Társaság tevékenységében viszonylag fontos szerepulk volt az útleírásoknak. Az utazás a 18. században nemcsak divat vagy gyakorlati hasznú helyváltoztatás, hanem kulturális jelenség volt, ezért fogom részletesebben vizsgálni.

\subsection{Az utazás mint kulturális jelenség}

A XVIII. század különösen kedvezett az utazási müfajoknak. A számos felfedezés új utakat nyitott meg, már nemcsak Európa, Föld körüli útra is indultak az utazók. Az élményeiket később napló, útleírás, útirajz formájában közölték. Saját korukban a legolvasottabb müvek közé tartoztak az útleírások. ${ }^{121}$ A német irodalomban Goethe ltáliai levelei számítanak kiemelkedő példának, de jelentős G. Forster beszámolója is Cook második világkörüli útjáról, valamint Herder útinaplója. A francia útirajzírók közül Chateaubriand és Lamartine említendők meg. Az útleírások számos almüfaja ismeretes aszerint, hogy a realitás vagy fikció felé mozdítja el a szerző az események bemutatását. Az útleírás a tapasztalatok tárgyszerü rögzítésére összpontosít, az útirajz, úti levél és útinapló megengedi a személyes benyomások, hangulatok rögzítését is, az utazási regény pedig fiktív cselekményeket és hősöket jelenít meg. ${ }^{122}$

Magyar vonatkozásban a XVI.-XVII. században megjelenö napló és önéletírás kẻpezi a késöbbi utazási irodalom alapját. A személyes vagy hivatalos ügyben utazó, többnyire nemes származású politikusok, államférfiak általában napló formájában örökítették meg

\footnotetext{
${ }^{118}$ I.m. 173.

${ }^{119}$ I.m. 175.

120 I.m. 279.

${ }^{121}$ Egyed A, 8.

${ }^{122}$ Szerdahelyi, 1997. 81.
} 
utazásuk történetét. Az utazás fontosságảt, központi szerepét jelzi Forgách Mihály ${ }^{123} 1587$ ben Wittenbergben megjelent munkája, a Beszéd az utazásról és dicsőségérōl. A mủvet bevezető epigrammában így ír:

"Kiváncsi vagy mivel szerzett dicsóséget s hirnevet magának Odüsszeusz? Elment a világ végére, felkeresett sokféle emberfajtát, sokféle várost, s ezzel szolgált rá, hogy e kerek világon beszéljenek róla. Ha tehát dicsö hírnevet akarsz nyerni, keresd fel Odüsszeusz példájára a távoli országokat! Ezt tanácsolja, ime egy elökelổ nemes föur, ki saját tapasztalatából ismerte meg az utazás sok elönyét. Öt kövesd útmutatódul, magyar ifjúság. ha nem akarsz alulmaradni, s készakarva eltékozlója lenni dicsốségednek.. "124

Ezután a szerző leírja az utazás módját és felsorolja a belöle származó hasznos következményeket. Kiemeli a „,bölcsességet és tudományt”, mert „mindkettö egy és ugyanaz az utazással". 125

A XVIII. század második felében már nemcsak tanulási szándékkal indultak peregrinációba az utazók, hanem kedvtelésből és tudományos céllal is. Ilyen céllal utazott Aranka György először 1793 őszén, majd 1797 nyarản a Székelyföldre.

\subsection{Egy erdélyi értelmiségi utazása}

Aranka György a Nyelvmívelő Társaság titkáraként szẻleskörü levelezést folytatott a már meglévő munkák felkeresése és az ủj, tudományos munkák megírảsa érdekében. A levelezés mellett azonban egy másik fontos módja volt a kéziratok, szövegek felkutatásának, hogy Aranka maga indult gyủjtỏútra. Ez a tẻny azért fontos, mert eddig egy ilyen jellegü utazásról tudunk: Bél Mátyáséról, aki 1720. júliusában kért és kapott engedélyt arra, hogy ő maga vagy megbízottja gyüjtés céljából bejárhassa több vármegye helységeit. Annyi volt a megkötés, hogy a helyi hatóságoknál jelentkeznie kell, s vallásüggyel nem foglalkozhat. A bejelentések hatására azonban néhány nap múlva a Kancellária megtiltotta Bélnek az utazást, annak ürügyén, hogy ilyen engedély csak királyi hozzájárulással adható. Elrendelték kihallgatását, hogy megtudják, vajon kinek dolgozik. Bél végül megkapta a királyi beleegyezést és folytathatta munkáját. ${ }^{126}$

A két utazás között több mint hetven év telt el, megváltoztak a politikai, társadalmi körülmények: Aranka már szabadon utazhat, bármiféle engedély nélkül, nincsenek megkötések a kutatott területet illetően sem. Figyelemre méltó, hogy a protestáns Aranka milyen tudósi és emberi érdeklödéssel fordul a csíksomlyói katolikus nyomda felé. Nem jelentenek akadályt a felekezeti különbözőségek, a titoknokot érdekli a másság.

Az utazás feltétele ez esetben a Kéziratkiadó Társaság megbízása, ezt Aranka 1792ben kapta meg, 1793. augusztus 27-én meg is erösítették. Az utazás célja az Erdẻlyben lappangó kéziratok, történeti munkák felkutatása és összegyŭjtése volt, a költségeket a Társaság állta. Aranka szeptember elején utazott, és már november 10-én benyưjjtotta jelentését.

\footnotetext{
${ }^{123}$ Förgács Mihály (1569-1603) - Forgács Simon fỏkapitány fia, Forgáca Ferenc esztergomi érsek testvére, sttassbourgi, wittembergi és olaszországi tanulmányút után 1592-ben tért haza, ifthon katonai pályán tevékenykedett

${ }^{24}$ Forgács Mihály: Beszéd az utazásról és dicsöségéröl. In. Kovács 1980, 8.

${ }^{125}$ Uo.

${ }^{126}$ Szelestei, 1989, 67-68.
} 
A következö évben Magyarországra utazott a titoknok, ahol a pesti egyetem és néhány fớri gyüjtemény kézirattárát tekintette meg: a Hadik Andrásét, Széchényi Ferencét, Festetics Györgyét, Teleki Józsefét, Prónay Sándorét és Szirmai Antalét, sőt Bécsbe is eljutott.

Harmadik alkalommal a Nyelvmívelö Társaság megbízásából 1797. augusztus 5-29. között járta be a Székelyfơldet, részben korábbi útvonalát követve. Erröl számol be ugyanazon év szeptember 4-én és 5-én a Nyelvmívelő Társasảgnak. Célja ez esetben többirányú, a begyüjtött anyag is nagyon heterogén.

Az első dolog ami feltünik a három utazást illetöen, az ủtvonalak különbözősége. 1793-ban és 1797-ben Székelyföldre utazik, a bejárt terullet Erdélynek kevesebb, mint fele. Vajon miért választotta ezt az útirányt? Csak megbízásának tett eleget, vonzotta öt családjának származási helye, Zágon, vagy a székelység mássága? Talán ebben az ősinek tartott országrészben remélt megtalálni fontos és értékes adatokat, kéziratokat? Mảsodik alkalommal ismét ellátogat Csíksomlyóra, nyilvánvalóan nem különíthetjük el egymástól a köz- és magánérdeket. Elsődleges és fontosabb is volt az elöbbi, de maga Aranka is beismeri az 1793-as utazásáról tett jelentésben, hogy negyedik célja saját könyv- és okiratgyüjteményének bővítése volt. Valószínủ, ebből is következik a későbbi tulajdonjog problémája: sokszor vita tárgyát képezte, hogy az Arankánál lévỏ kéziratok, könyvek valójában hova is tartoznak, mi a titoknok tulajdona és mi a Nyelvmívelö Társaságé. Nem azt szeretném bizonygatni, hogy Aranka a Nyelvmívelö Társaságtól fontos dokumentumokat tulajdonított $\mathrm{el}$, inkább rákérdeznék arra, mi is vezetett később számos félreértéshez. ${ }^{127}$

A másik útirány Debrecen-Budapest-Bécs. Ebből arra következtethetünk, hogy a magát Erdélyi Nyelvmívelö Társaságként definiáló tudós társaság tágabb határokban gondolkodott, mint amit a fóldrajzi régió implikál. Nyilván tudta Aranka, hogy a fóni és egyetemi könyvtárakban számos értékes kézirat lappanghat. A két programiratban a haza szót használja, nem jelölve meg egyértelmủen, hogy Magyarországra vagy Erdélyre gondolt-e. Valószínúbb az utóbbi, mivel Erdély közjogi helyzete folytán önálló volt, közvetlenül a koronának volt alárendelve. Ami az utazások sorản összegyủjtött anyag mennyiségét és minőségét illeti, mindenik külön dolgozat alapját kẻpezhetné. Én az első székelyfơldi utazás anyagát és körülményeit vizsgálom, az erre vonatkozó jelentés alapján, néhány vonatkozásban összevetve a második utazással. Itt tartom helyesnek közölni az utazásról szóló jelentést.

1793-ban Keresztúr - Udvarhely - Homorỏdszentmárton - Barót - Köpec - Hídvég Uzon - Sepsiszentgyörgy - Alsócsernáton - Jakabfalva - Csíksomlyó az ủtvonala, négy évvel késöbb a Szováta - Parajd - Gyergyỏcsomafalva - Csíkmadaras - Csíksomlyỏ Kézdivásárhely - Zabola - Gidófalva - Brassỏ - Hídvég - Köpec - Ürmös - Kỏhalom Fehéregyháza - Marosvásárhely vonalon járja be a székely székeket. ${ }^{128}$ Mindkét alkalommal több kézirattal, naplóval, feljegyzéssel és számos földrajzi, biológiai megfigyeléssel tér haza.

\subsection{A szövegközlés elvei}

Amint azt már A feltárás módszerei címủ fejezetben jeleztem, a német Wolfgang Pross elméletét véve alapul, a szöveget filológiailag fogom értelmezni. A szöveg

${ }^{127}$ Aranka még életében kezdte szétosztani gyủjteményét. Vẻgrendeletét illetỏen lásd: Egyed, 200b. 134-137.

${ }^{128}$ Jancsó, 1955, 241-245 
helyesírásán nem változatattam, olyan esetben, ahol egyes szavak félreértésre adnak okot, a magyarázatot lábjegyzetben közlöm. A röviditések feloldását, az esetleges hibát, törlést vagy betoldást szintén lábjegyzetben jelzem. Megtartottam a szöveg kéziratbeli elrendezését, a számozást, a kiemeléseket és aláhúzásokat. A zárójelben szám jelzi, hogy ủj oldal kezdödik a kéziratban. A kéziratban elöforduló neveket a dolgozat végén névmutatóban pontositom.

\subsection{A jelentés}

\section{ARANKA GYÖRGY JELENTÉSE}

SZÉKELYFÖLDI TUDOMÁNYOS UTAZÁSÁRÓL

Az erdélyi m. nyelvmív. ${ }^{129}$ Társaság irományaiból,

Vass József könyvtárnok felügyelése alatt, másolta Mák Ferenc, a kolozsvári rom. kath. ${ }^{130}$ nagy gymnasiumban Vlll-d. osztálybeli tanuló 1852.

Nagy Méltóságú Fökormányzó Úr,

Méltóságos Fö Tanács,

Kegyelmes és kegyes, jó, Méltóságos Uraim!

(1) Excellencziátoknak 1792-dikben Mind. szt. hava ${ }^{131} 21$-én lett, és e folyó esztendöben Boldog Asszony hava ${ }^{132}$ 27-én megujitott parancsolatjoknak, s az én tulajdon ajánlásomnak rendében jelentem Excellencziátoknak alázatosan: hogy azoknak a k.k irásoknak, ${ }^{133}$ mellyeket T. ${ }^{134}$ mostani köpeci reform. ${ }^{135}$ pap Benkõ Jozsef ${ }^{136}$ uram bir, és a mellyekböl ö $\mathrm{klme}^{137}$ maga a Mlgs ${ }^{138}$ Fỏ Tanácsnak jelentést tett volt, meglátása, és azoknak vagy a haza számára való megszerzések, vagy irántok való bizonyos alkalomtétel végett, a mult Kis Asszony havában ${ }^{139}$ Köpecre, nemes Miklósvárszékbe elmenvén: Excellencziátok parancsolatjának kivántam alázatosan eleget tenni; de szándékomat nem telyesitettem: mindazért, hogy ö klmét a rajta levő forró hideg miatt ollyan gyenge állapotban találtam, hogy harmadnapig mulatván nála, alig nyerhettem annyi idöt, hogy hellyesen egy két órát tevő ideig vele csendesen szólhassak; mind pedig azért, hogy könyvei és írásai Köpecre való költözködése után, nem csak épen ${ }^{140}$ semmi rendben nincsenek, a mint által hozattak Közép Ajtáról, még most is a szerint ládákba lévén rendetlenül rakva, hanem nagy részök Közép Ajtán is vagyon. Azért nem lévén egyebet mit tennem, T. Benkõ Jozsef Urammal illyen alkalomra mentünk, és igy végeztünk:

Hogy elsöben, ezen az öszön Isten eröt adván ő kelmének, ő kelme minden kézírásait egybegyüjti, és azokat egy lajstromba szedi, feljegyezvén mindenik mellé; hogy eredeti-e vagy nem. Ưgy pedig://

\footnotetext{
${ }^{129}$ Értsd: magyar nyelvmivelö

${ }^{130}$ Értsd: római katolikus

${ }^{1 s 1}$ Mindszent hava, azaz október

${ }^{132}$ Január

${ }^{133}$ Értsd: kézírásoknak

${ }^{134}$ tiszteletes, a továbbiakban még a tisztelendő̉t is így rövidíti

135 református

${ }^{136}$ a József nevet következetesen rövid o-val írja

${ }^{137}$ kegyelme

${ }^{138}$ Méltóságos

120 augusztus

${ }^{140}$ az éppen szót egy p-vel írja
} 
(2) Másodszor: Hogy azokat, mellyek nyomtatás alá, vagy ha csak jó és szép másban is tisztán le vannak irva, megkülönböztetvén a többitől, azoknak utánna teszi jegyzésben, hogy hány arcusból ${ }^{141}$ állanak, és mi az árrok ${ }^{142}$, ugy a többinek is felirja, hogy mellyikért mit kiván, és ezt a lajstromot mostani sz. Márton napjára kiküldi: melly fogadását mint teljesíti, vagy teljesítheti, nem tudhatom, mivel azután ő kelméről semmit sem érthettem. Most a sokadalmi alkalmatossággal, ha arra embert találok, vagy a királyi tábla folyása alatt, ha arról felöl székelyek jőnek, ismét serkenteni fogom.

Én ott mulatásommal az ő klme ládáit felhányván ezeket találtam:

1-ör) Boytinus de rebus gestis Gabrielis Bethlen libri 3, in fol. deákul.

2-ór) Rákoci ${ }^{143}$ Ferenc levelezései 1704-1711.

3-ór) Bethlen János historiája, tulajdon keze irása deákul.

4-er) Csíki Cserei Mihály jegyző könyve 1631-1658 magvar kicsid.

5-ör) Andreae Scharsii ordinata digestio status Saxo-Ecclesiastici in Trannia. ${ }^{144} 1706$, ugyan evvel Archaeologia. Deákul.

6-or) Schmeizel compendium historiae civilis, et Ecclesiasticae Trañniae. Deák.

7-er) Haller Gábor diariuma 1629-1643 magyar 14 árkus kész.

8-ór) Kálnoki István diariuma 1644. 2 árkus kész.

9-er) Rhedei László diáriuma 1653-1657 kész.

E mellett 10-er) Kemény János Ruina exercitus Trañnici, és a fejedelemhez $\mathbf{s}$ rendekhez küldött levele 4 . árkus. Ez a ruina és levél nem tétethetik a Rhédey László diáriuma mellé semmiképpen; mert ez az Enyedi István k. irásába, melly 1657-ik esztendõ szám alatt vagyon a Társaság lajstromában, a történetek leirása rendében, ugy bé van szóról szóra fog- // (3) lalva, hogy onnan kivenni nem lehet, kétszer pedig kiadatnia helytelen.

11-er) Vízaknai Britius diariuma ${ }^{145}$, a kurucvilágról, 1703-1711. 4 árkus.

12.er) Török Ferenc diáriuma 1681-1683. egy árkus.

13.or) Szalárdi János napló-könyve, csonka 1632. 7 árkus.

14.er) Dálnoki Veress Gerzson kuruc-világról írt versei 10 árkus.

15.ör) Balog László diáriuma.

16.) Egri Fodor Sámuel diariuma I-ő Apaffi Mihálynak Érsek Újvár alả meneteléröl, ott léte s haza jöveteléröl.

17.) Martini Schmeitzel collegium in historiam ad statum regni Hungariae.

18.) Xilander historia Motuum Bocskaianor. 1604-1606. Ezeken kivul igen jeles ártikulusokat és diplomák gyújteményét.

A fentebb irtakról pedig azt jegyzem meg:

a.) Az 1-ső szám alatt való Bojtit. ugy a Mikó Ferenc kézirását is $\mathrm{T}$. Benkő uram már ez előtt sajtó alá adta, sőt el is adta Hochmeister uramnak az elsőbbet 15, vagy 25 rh forinton, a mást mennyiben nem tudhatom. Mellyet Excellencziátoknak azért jelentek, hogy ha Hochmeister uram elöre kiadja, a társaságnak rövidséget teszen, vagy maga kárt vall. $\mathrm{E}$ pedig mindenik nevezetes darab.

Azt is jelentem továbbá Excellencziátoknak alázatosan; hogy talán az elsőre is; de nevezetesen Mikóra $T$. Benkő uram némely jegyzeteket tévén, hogy a könyvnek ${ }^{146}$ illö $^{\circ}$ nagyságot adhasson, valamint az azon idöbeli apróbb $\mathrm{k}$. I. beli krónikákban kapott, a szépẻt és javát mind belé irta; ugy hogy azoknak majdan // (4) kiadások haszontalan költés, ki nem adások ellenben nagy kár lenne. Ezt én megértvén, öklmével is megértetvén, még onnan

\footnotetext{
141 ivbỏ!

142 áruk

${ }^{143}$ Rákóczi helyett

${ }^{144}$ a Transylvania szó rövidítése

${ }^{145}$ a szóban az $u$ betủ sor folötti betoldás

${ }^{146}$ a szóban az. $n$ betű sor fölötti betoldás
} 
helyböl Köpecröl mindjárt irtam Hochmeister uramnak, hogy tovább való rendelésig, Mikóhoz hozzá ne fogjon, és ezt a levelet, magával Benkö uramal subscribáltattam. ${ }^{17}$ Excellencziátok már tovább méltóztassanak bölcsen végezni, és rendelni ezek irảnt.

b.) A 7-ik szám alatt levö k. 1. nak az eredeti irása M. püspök Excellencziájánál ${ }^{148}$ vagyon.

c.) A 11-dik szám alatt valónak eredeti irása pedig T. Doctor Pataki uramnál vagyon.

d.) A 14-dik szám alatt valónak eredetie nálam van.

e.) A 16-ik szám alatt valót megnézvén, nem találtam egésznek.

f.) Közönségesen pedig mind azokról, mellyekrõl azt irtam hogy készek, ezt jegyzem meg; hogy e csak azt teszi, hogy tisztán le vannak irva, de ollyan módon, mint a társaág akarja, és illik kiadni, po ${ }^{149}$ az iró élete leirásával, akkori irásmódját, $\mathrm{s}$ történetét illető világositásokkal épen nincsenek kidolgozva. A T. Benkö Józef uram gyüjteményeiröl többet nem tudok irni Excellencziátoknak. Hanem, még megindulásomkor tartván a kitudjától, és szélesebb céllal, s nagyobb készulettel indulván meg, már tudositom arra nézve is Excellencziátokat. Azonkivủl t.i. ${ }^{150}$ elsỏ célt ezt_tettem volt föl magamnak: hogy ha mi a k.k. irások társasága (számára) ${ }^{151}$ tárgyára szukséges kézirások a székely földén még hevernének, azokat felkeressem, ezen részben ennyi haszonnal jártam; találtam:

1. Szitás Kereszturon a reform papnál T. Kis András uramnál egy Székely István régi nyomtatott kronikájának a végén egy k.irás toldalékot, régi irást, mellyet $T$. Kis András uram kezem- // (5) be küldvén, mivel igen nehéz irás, haza jövetelem után, épen azon irás módját tartván, melly az eredetiben vagyon, magam kezemmel leirtam.

2. Udvarhellyen, vagyon a városnak egy 70 esztendöt meghaladott nótáriussa Szeles Márton, kalmár céhbeli de deákos, és olvasó ember, kihez mikor kalmárboltjába mentem, akkor is az Apuléjus arany szamara ${ }^{132}$ volt kezében és azt olvasgatta. Ennél találtam:

Udvarhely várossának igen szép és ió diplomatica leirását.maga kezeirása, és munkája, mellyet a magyar társaság gyủjteményei közé ajánlván, a közjỏra nékem által adott, és el is hoztam. Ugyan:

Egy igen szép verses könyvét, ez is maga munkája, de ezt, nem lévén célomra, nem hoztam el. És ismét:

3. Udvarhelyen katholikus káplán T. Pater Dobránál találtam kẻzirásban n. Pater Lakatos Siculiáját, a tulajdon maga szép kezeirását; mellyet subregens T. Ágota úr vévẻn kezéhez, hogy számomra jól leiratja. és összenézi; még kezemhez nem kaphattam; most irtam iránta.

4. Ugyan Pater Dobránál találtam n. Director Dobra urnak Gyergyóról irt szép deák verseit, de megolvasván ơket, nem itéltem olyanoknak, hogy a k.k. társasága céljának megfeleljenek.

5. Sz. Mártonban Kovács László úrnál találtam szép diplomák gyüjteményeire, a mellyeknek lajstromát fogadta, hogy elküldi.

6. Miklosvár székében Baróthon Mlgs főstrảsa mester Mỏsa László urnál talảltam a haza régibb állapotának ismeretére sok szép gyüjteményt kézirásban. Nevezetesen:

Gálfalvi Veress Gerzson kurucvilág leirását, a maga tulajdon irását, mellyet Mósa ủr által engedett. Igen igen nehéz és rossz irás, mivel a szerzỏ grammatikát sem tanult volt, ha Excellencziátok parancsol, hogy leiratása jó legyen a társaság számára leiratom szemeim elött. //

(6) Mikó Ferenc historiaját a Biró Sámuel ugyan akkori folytatásának toldalékjával, nem eredeti irás. A m. ${ }^{133}$ társaság számára ajánlotta, a föstrása mester úr.

147 aláírattam

${ }^{148}$ Batthyány Ignác püspöknél

149 példának okáért

150 tudniillik

is! ezt a szót a másoló zárójelbe tette, és áthúzta

${ }^{152}$ Apuleius római író híres, Metamorphoses, más néven Asinus aureus (Aranyszamár) címủ mủve 
N. idősb Mósa László úr Erdély diplomatika históriáját 1686-1743-ig. Ezt most szedeti rendbe a mgs főstrása mester, és ha elkészül a k.k. társaságának által igérte. Emlékezett továbbá egy T.

Tordai T. historiájáról kézirásban. mellyet $n$. Siskovics Generalis ủr elvivén most az özvegyétöl várja vissza: ezt is ha megérkezik általígérte.

7. Köpecen t. Benkő urnál a miket találtam, azokról feljebb vagyon emlékezet.

8. Hídvégen mgs gróf Nemess Ferenc úrnál találtam egy igen szép ujadon új kézirásra, ez a : N. idösb Nemess János diáriuma 1651-1686. egészen a maga keze irása, egy egész jókorú könyv telik belöle. Ez a kézirás néhai gróf Nemess János úr ő Excellencziája halálával mlgs gróf özvegy Haller Jánosné ő nagysága által kerülvén kézre, az ő nagysága tetszéséből elébb megyen mgs báró özvegy Korda Sigmondné ö nagysága kezére, azután onnan igyekezem a társaság számára vagy leiratni, vagy inkább magát megszerezni.

9. Uzonban létemben ugy esett értésemre hogy mlgs gróf Kálnoki Lajos Tanácsos úr ő nagyságánál nemzetségi leveles ládájában vagyon:

Kálnoki Istvánnak Konstantinápolyi utjáról való diáriuma, eredeti irás: mellyről feljebb a t. Benkö Jozsef uramnál talált kézirások között emlékeztem.

Nemkülönben $\underline{n}$. gróf cancellarius Kálnoki Sámuel urnak két diáriuma, egyik rendes könyvben, másik egy kalendáriom tiszta leveleire írva, ez a két utolsó ujadon új találmány, méltóztassanak Excellencziátok ő nagyságától kinyerni.

10. Sepsi sz. Györgvön. vagyon egy igen érdemes és hazáját sze-// (7) rető reform. pap T. Kocsis Sámuel uram, az ő klme tudósításából értettem, hogy az Alcsernátoni ${ }^{154}$ reform. ecclesia $^{155}$ jegyző könyvében vagyon egy kicsi haza krónikáját illető kézirás; módom nem lévén benne, hogy megnézzem $\mathrm{T}$. Keresztes Máté uram Kézdi-Vásárhelyi reform. pap és gralis notárius ${ }^{156}$ igérte, hogy leiratván kiküldi, de még nem vettem, ide is irtam, és sürgettem.

11. Alsó Csernátonban mlgs föstrása mester Mihálc úrnál megtaláltam, a néhai édes aty.ja keze irását a philippica siculicát. mellyet a jó úr a társaság számára a kezembe adván, lehoztam, és mlgs tanácsnak által fogom szolgáltatni.

12. Kászonszékben Jakabfalván Tkts Kovács Dániel urnál igen sok szép kézirásbeli gyüjteményt_találtam, mellyekböl velem is néhány darabokat közlött: legnevezetesebb a Lajos király seregeinek a mohácsi ütközet elött való éneke, mellyet rendében kifogok ${ }^{157}{ }^{a d n i}$; mivel igen aprólék, de szép régiség.

Itt Jakabfalván egy kutya a lábomat szerencsétlenül megmarván, melly miatt mégmost ${ }^{158}$ is házban ülök, Csik és Gyergyó székeken csak által futottam, sietvén haza felé, és többé vizsgálódásomat nem folytathattam. Hanem:

13. Csík-Somlyóban a sz. Ferenc szerzetbeli szürke barátok conventjében ${ }^{159}$ elkerülhetetlen szükségesnek tartottam megállapodni. kiváltképpen a nyomtató mühely kedvéẻt.

Kegyelmes Uram és Mlgs Tanács, ennek a nyomtató mühelynek szép betüire és nyomtatására nézve kétség kivül egész Erdélyben nincsen párja. Ennek bizonyságául, melléje zárok ezen irásomnak két imádságos könyvecskét, mellyet mindeniket onnan vettem. És a többit Excellencziátok bölcs tanácsára bizom. Hanem Excellencziátoknak illỏ megérteni ezeket:

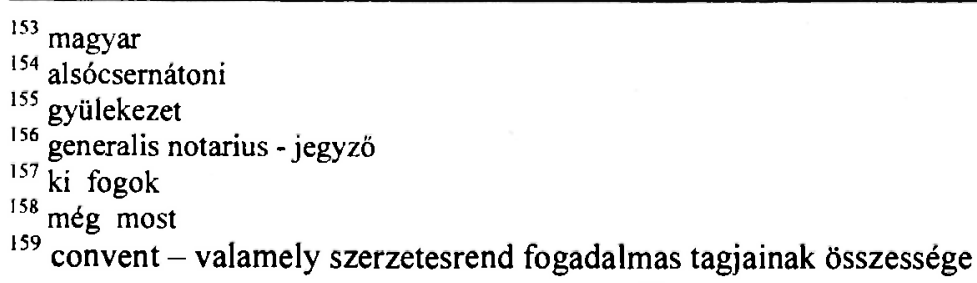


Hogy most olyan parancsolat vagyon, hogy ebben // (8) a sajtóban csak kegyes könyveket szabad nyomtatni.

Hogy csak egy szedő legény vagyon, a ki volt még egy frater, Nepomucénus, SzamosÚjvárra tétetvén által.

Hogy mind arra nézve, mind a sok inneplés ${ }^{160}$ és imádság miatt szerzetesek lévén, a munka oly lassan menyen ${ }^{161}$, hogy egy árkust egy hét alatt ki nem szedhetnek.

Hogy a mühely nem a conventé, hanem a provinciáé, ${ }^{162}$ és ha mit az ember a fenn irtakban segélni akar, a pater provincialissal ${ }^{163}$ kell iránta végezni; azután frater Miklóssal kell egyet érteni, helyben ő lévén, a kitől minden függ.

Hogy a nyomtatásra való költség igen türhető, mellyet frater Miklósnak ide zárt levelébỏl Excellencziátok megtalálni méltóztatnak. De ezt a levelet nékem méltóztassanak első alkalmatossággal vissza küldeni, szükségem lévén reája. És első célomban lábomon esett szerencsétlenségem miatt csak ennyire mentem .

Második. De mellesleg való célom ebben az utazásomban a volt, hogy a kiadandó kézirások rendébenn Excellencziátok nevezetesen a Marosszék tisztségeinek nemek és ágok szerint való viselésének (:a lajstromban 1505-dik esztendő szám alatt:) kidolgozását réám méltóztatván bizni; és abban a nemek és ágok (: tribus, et generationes:) különbsége elöfordulván; ezen részben a székely fôldön valami világositást vegyek; de ebben épen telyességgel semmire nem mehettem.

Harmadik célom volt, hogy Kászonszék eredete leirásának, a kiadásra való elkészítése a lajstromban legelől, hasonlóképen réám bizattatván: annak eredeti kézirását felkeressem; mivel sok ${ }^{164}$ utánna való // (9) járásom és levelezésem után is a mellyeket találhattam, mind hibásak. Ezen részben Kászonszékben, Jakabfalván, Tkts ${ }^{165}$ Kovács Dániel urtól a szék privilegiumainak másait megtalálván, arra ugyan elegendỏ prỏbát kaptam, hogy az az irás, és a dolog igaz, $\mathrm{da}^{166}$ magának az eredeti irásnak másutt soholt ${ }^{167}$ nyomába nem akadhattam, csak mgs gróf Lázár István urnál; könyörgök azért Excellencziảtoknak, mẻltóztassanak gróf Lázár István urat magok megtalálni, hogy azt a Kászoszéknek Csíktól való elszakadásáról, és eredetérỏl szóló régi magyar kézirást, Excellencziátok kezẻbe adja ki. Tovảbb szükségem nincsen reá, csak a még nálam levő másával egybe nézem, és vissza adom: $s$ a reảm bizott két darab irásokat elkészitve Excellencziátok eleibe mindjárt alázatosan béfogom ${ }^{168}$ nyújtani. Negyedik célom volt; hogy kevés diplomákbeli gyủjteményemet ujabb darabokkal, magyar könyves polcomat régi és ritka magyar könyvekkel, és a magyarok viselt dolgait megirt iróknak nyomtatott könyveikből álló kevés gyüjteményecskémet is szaporitsam, és mind a magyar nyelv mivelésére, mind az avval egybeköttetett sokféle igyekezetekre szerte szélyel társakat keressek, és nézzek ki: mellyekben nem voltam épen szerencsétlen. Utolsó célom pedig az volt, hogy megpróbáljam egy utazásocskảt tenni hazảmban, és azt megirván, magyar nyelven kiadni; hogy a hazafiainak közönségesen egy jó példát, jó elméknek pedig csekély igyekezetemmel egy új ösztönt adjak; s e szerint hazánk ismerete, mind természeti, mind polgári, és más állapotjaira néz-// (10) ve részenkint és lassan ez által közönségesebbé tétetődvén a hazában; ne kénytelenittessünk ezután is örökké, mint eddig, hazảnk ảllapotját

\footnotetext{
160 ünneplés

${ }^{161}$ megy

162 tartományé

${ }^{163}$ szerzetesrend tartomanyi rendfonökével

${ }^{164}$ a szó sor fölötti betoldás

${ }^{165}$ Tekintetes

${ }^{166}$ de helyett

${ }^{167}$ sehol

168 bé fogom
} 
idegenektỏl rosszul,, ${ }^{169}$ és azoktól tanulni meg, kiknek abban a részben természet rende szerint, ha jól és igazán akarják hazánkat ismerni: csak mi tőlünk kell leckét és utositást venni. Erre nézve nem vontam meg figyelmességemet a szántás vetéstỏl; fonástól és más mesterségektől, azokat a tárgyakat, mellyek a természet esméretét; (: naturalis ${ }^{170}$ historiát:) illetik mindenütt, nevezetesen az Almási lyukakat, és csodáló köveket, a bálványos várat, a bưdös hegyet, ennek büdös lyukait és terméseit, $\mathrm{s}$ több apróbbakat meg jártam, megnéztem, a helységek terméseibỏl pedig, minémü az osdolai gyémánt kö is, a természet országából már elkezdett kicsi gyüjteményecskémben magammal hoztam. Mellyeknek bővebb leirása, nem ezen irásomhoz tartozván azokat majdan, mikoron utazásomat kiadom, Excellencziátok közöl a kiknek az affélékre ưres ideje és kedve lészen, ha fog tetszeni, megláthatja.

Mind ezekről előbb tudositottam volna alázatosan Excellencziátokat, de remélvén lábom meg gyógyulását, személyesen akartam tudósitásom mellett udvarolni. Most pedig békövetkezvén a szolgálat napja, alázatosan bényujtom csekély tudositásomat. Ezeken kivül még ezt is bátorkodom alázatosan jelenteni:

Hogy még a mult esztendőben találván itt M.Vásárhelyt ${ }^{171}$ egy igen szép kézirást, u.m. ${ }^{172}$ a Bor-// (11)sos Sebestyén, és Nagy Ferenc marosvásárhelyi lak(at)osok ${ }^{173}$ diáriumát, melly Mátyás királytól vagy közelebb a mohácsi veszedelemtõl fogva 1657-dik ${ }^{174}$ hozza le a krónikát igen szépen. Ezt a diáriumot, mlgs gróf Haller Sigmondné ő nagyságánál találván, az eredi ${ }^{\mathbf{1 7 5}}$ régi irásban, $\mathrm{s}$ ő nagysága engedelméböl leiratván, a társaság számára taval ${ }^{176}$ bé vittem volt egy példában Kolosvárra, és vagyon mlgs püspök úr ő Excellencziájá ${ }^{177}$ kezénél. Ö Excellencziája maga számára, le akarván iratni. Ez a társaság gyüjteményei közé való: iratásának árát nem tudom megirni, csak azt tudom, hogy nehéz $\mathrm{s}$ bajos irás lévén, minden árkusért 18. krajcárt fizettem, s a kötésért azonkivül.

Mostani úti költségem pedig, mellynek megforditását Excellencziátoktól alázatosan kérem; tészen:

$$
\begin{aligned}
\text { a szekeresnek } & =\text { m. f. } 40 . \\
\text { úti költség } & =" \text { " " } \quad 36 . \\
\hline \text { összeg } & =\quad 76 .
\end{aligned}
$$

Melyrỏl nyugtatványomat alázatosan ide zárom, ẻs magamat Excellencziảtok kegyességébe ajánlván, vagyok

Excellencziảdnak és a mlgs fö Tanácsnak alázatos szolgája

M. Vásárhely 10-dik 9 ber $^{178} 1793$.

\footnotetext{
${ }^{169}$ rosszul

170 az ur szótag sor fólótti betoldás

${ }^{171}$ Marosvásárhelyt

${ }^{172}$ ugymint

${ }^{173}$ az at szótag zárójelbe van téve és ki van húzva

174 1657-dik jelenik meg valószínủ az 1657-ig helyett

175 eredeti helyett

${ }^{176}$ tavaly

177 a szó végéról törölve van a nak rag

${ }^{178}$ november
} 


\section{A jelentés értelmezése}

\subsection{Tartalmi szempontú vizsgálat}

Aranka elöször a Köpecen, Benkö Józsefnél tett látogatásáról számol be és felsorolja a nála talált 18 kéziratot. Bár Köpec utazásának csak a 7. állomása, mégis kiemeli, első helyre teszi, mert Benkő gyüjteménye a legjelentősebb.

Benkỏ József megalakulása óta támogatỏja és levelező tagja a Társaságnak. Aranka már 1792 novemberében megírja neki, hogy Középajtára szeretne látogatni ${ }^{179}$, és Benkő is tervezett egy marosvásárhelyi utat. ${ }^{180}$ Amikor Aranka Székelyföldre utazik, Benkő már Köpecen lakik, de könyveinek nagy része még Középajtán van. Mivel Benkö beteg, nem is tudnak ,hellyesen egy két órát tevő ideig” beszélni, mondja Aranka. Benkö mégis megígéri, hogy könyveiről címjegyzéket készít és a ,lajstromot” a Társaságnak beküldi.

Aranka nyolc diáriumiot - naplót - talált Benkőnél, öt történelmi munkát, egy levelezést (a Rákóczi Ferencét) és két históriát. Elhozta még Dálnoki Veress Gerzsonnak a kuruc világról szóló verseit. A címek után feljegyzi a terjedelmet és egyes esetekben a kézirat nyelvét. Ezután felsorolja a kéziratok eredetijẻnek lelőhelyeit. A letisztázott munkák sem készek a kiadásra, mert

„po. Az iró élete leirásával, akkori irásmódját, s történetét illetõ világositásokkal épen nincsenek kidolgozva."

Aranka e kijelentéséböl arra következtethetünk, hogy komoly filológiai munkát óhajtott végezni a talált kéziratokon. A mondottak szerint biográfiai, történeti adatokkal egészitette volna ki a szövegeket. Azonban nem tudunk róla, hogy ezt megvalósította volna.

Aranka első céljaként a kéziratok felkutatását határozza meg. Ezután helysẻgek szerint sorolja fel a megtalált írások címét, de néha csak a lelőhelyet, máskor utal a kézirat állapotára is. Megemliti jakabfalvi balesetét - egy kutya megharapta -, majd a csíksomlyói ferences kolostorban tett megfigyeléseiröl számol be. Megkülönböztetỏ figyelemmel ír a nyomdáról, és öt pontban össze is foglalja észrevételeit. Mellékel a jelentéshez két, itt készült imádságos könyvet. A mühely a provinciáé, ezért a változtatások érdekében a pater provincialis-szal ${ }^{181}$ kell beszélnie. Aranka mellékel egy levelet György szerzetestől amelyböl - szerinte - kiderül, hogy a nyomdai költségek nem nagyok.

Itt kell megjegyeznünk azt, mennyire fontos szerepet játszottak a XVIII. századi Magyarországon a nyomdák, amelyeknek ekkorra ugrásszerủen megnövekedett a számuk. A nyomdák felekezet szerint oszlottak meg, többek között híres jezsuita nyomda volt Nagyszombatban, protestáns nyomdák Debrecenben és Kolozsváron. A jezsuita rend megszüntetésével (1773) azonban csökkent a katolikus egyházi nyomdák száma. Egyre több polgári vállalkozás jött létre, amely bármilyen felekezetü mü nyomtatását vállalta, így ötszörösére nött a kiadványok száma a korábbiakhoz képest. ${ }^{182} \mathrm{~A}$ csíksomlyói ferences rend nyomdája 1676-ban létesualt, ez volt Erdély első katolikus nyomdája. Alapitója Kájoni János rendfonök, aki 1675-ben került Csíksomlyóra. Kájoni érdeme a katolikus egyházi énekek összegyüjtése, amelyet 1675-ben adott ki Cantionale catholicum címmel. A nyomda föleg helyi jelentöségü volt, vallásos kiadványokat, naptárokat adott kỉ a környezö falvak

\footnotetext{
${ }^{179}$ Aranka György Benkő Józsefnek, 1792 november 11, Marosvásárhely

${ }^{180}$ Benkő József Aranka Györgynek, 1792 november 26, Középajta

${ }^{181}$ szerzetesrend tartományi rendfönökével

${ }^{182}$ V. Ecsedy, 1999,16. skk.
} 
lakossága számára. ${ }^{183}$ Aranka felismerte a nyomda értékét, 1797-es utazása során is ellátogatott ide, és több napot tơltött a kolostorban. ${ }^{184}$

Az utazás második céljaként Aranka Marosszék tisztségeinek „nemek és ágak szerinti" összegyüjtését nevezi meg. Aranka bevallása szerint egy már meglévő munkát kell kidolgoznia. Valószínü, hogy egy sematizmusról van szó. Harmadik célja, a Kászonszék eredetét bizonyító okirat felkutatása, nem valósult meg. A titoknok már rendelkezett az okirat másolatával, és -bevallása szerint - számos más forrásból arra következtetett, hogy a nála levö írás hiteles ugyan, de az eredetit nem találta sehol. Feltételezése szerint gróf Lázár Istvánnál lehetett. Abból, hogy egy szükebb régió, Kászonszék eredetét is fel akarta kutatni, arra következtethetünk, hogy a Kéziratkiadó Társaság programjába belefért a konkrét helytörténet kutatása is.

Kászonszéken kívül nem tudunk olyan régióról, amelyet konkrétan vizsgált volna Aranka, a Társaság tervezetében általában Erdélyre vonatkozó történelmi munkák összegyüjtését sürgeti. ${ }^{185}$ Valószínü, hogy mivel csak Kászonszékre vonatkozóan került elö adat, Aranka fontosnak tartotta hogy a már meglévö, biztosnak vélt irányban kutasson tovább, remélve, hogy bármikor felbukkanhat más, vidékekre, székekre vonatkozó adat is.

A negyedik cél már személyes: saját könyv- és okirat-gyüjteményét is bővíteni szeretné. Kissé óvatosan kell Aranka ezen kijelentéséhez közelítenünk. A titoknok ugyanis a Kéziratkiadó Társaság megbizásából utazik, gyủjt kéziratokat és kőnyveket, erröl hivatalos jelentést nyújt be a Társaság vezetőinek, mégis beleirja a jelentésbe - negyedik célként -, hogy saját gyüjteményét is szeretné bövíteni. Feltevődik a kérdés, mennyire volt hivatalos az utazás, mennyire volt szigorú Aranka megbízása, ha nem zárta ki azt, hogy a titoknok a maga számára is gyüjtsőn könyveket. Érzékeltetni szeretném, mennyire ambivalens volt a viszony Aranka és a Társaság között. Egyfelöl nagyon formalizált volt ez a viszony, Aranka nem számolhatott be csak szóban vagy egyszerüen levélben, hanem annak rendje és módja szerint meg kellett ímia a jelentést. Másfelöl azonban nemcsak a hivatalát teljesítő személy volt ő, hanem tudós, értelmiségi, utazó is, akinek természetes volt, hogy saját gyüjteményét is bövítette az utazás alkalmával.

Utolsó célja az volt, hogy egy „utazásocskát” tegyen, és azt megírva kiadja. Ezért kiterjedt figyelme a gazdasági, társadalmi, nẻprajzi eseményekre, tevékenységekre és földrajzi valamint biológiai jelenségekre is. Megígéri az ủtleírást, amelyet magyar nyelven szeretne kiadni. A jelentés e vonatkozására később mẻg visszatẻrek. A jelentés végén közli, hogy az azelötti esztendőben (azaz 1792-ben) talảlt Marosvásárhelyen egy naplót, Borsos Sebestyén és Nagy Ferenc munkáját, amelyet kiadásra érdemesnek talál. A jelentést az utazás költségeinek benyújtása zárja.

\subsection{Formai szempontú vizsgálat - a szövegvariánsok összevetése}

Mák Ferenc 1852-ben másolta le Vass József felügyelete alatt a szöveget. Kẻt év múlva 1854-ben jelent meg Vass tanulmánya az Új Magyar Muzeumban. A folyóiratban Vass Arankát jelöli meg szerzöként, de nem tủnteti fẻl a szöveg lelöhelyét, amelynek címe: Erdélyi utazás régi kéziratok ügyében. Azonban nemcsak a címek különbőznek, hanem maga a szövegtest is, ezért úgy gondolom, érdemes közelebbről megnézni az eltéréseket. Van a két verzió között néhány olyan eltérés, amelyet elírásnak vagy nyomdahibának

\footnotetext{
${ }^{183}$ I.m. 139.

184 Jancsó, 1955, 245-247.

185 Jancsó 1955, 102.
} 
minösíthetünk: pl. da szerepel a kéziratban de helyett, ${ }^{186}$ vagy Lázáz lstván az Új Magyar Muzeumban a Lázár István helyett. ${ }^{187}$ A folyóiratban közölt verzióban Vass József következetesen kiírja a rangokat, címeket: méltóságos, tanácsos, generális, míg a kéziratban csak ennek rövidített formáját találjuk: mlgs, gralis. A szövegek között vannak olyan eltérések is, melyeket szükségesnek tartok nyelvészeti, nyelvtörténeti szempontból is összevetni. A két verzió között mintegy hatvan év telt el, mialatt az írott és beszélt nyelvben számos változás történt. A kéziratot ezután V1, a megjelent változatot pedig V2-vel jelölöm. Egyes szavak esetén más hangalakot találunk, mert eltérỏ a fỏnevek toldalékolása és helyesírása.

V1: ideig, megszerzések, rendében

V2: idöig, megszerzésök, rendjében.

Az első esetben szabályos labializációval van dolgunk, az $e$ hang, mely ajakréses (illabiális) ö-vé alakult, így lett az ideig hangalakból időig. A második jelenség már bonyolultabb, a 19. században ugyanis többször megváltoztak a birtokos személyragozásra vonatkozó szabályok. ${ }^{188} \mathrm{~A} \mathrm{ma}$ is használt paradigma többes számban gyakran ingadozott, és vidékenként változott, ezért használhatta Aranka a megszerzések alakot. A 19. század közepén azonban a többes szám, harmadik személyü birtokos személyrag $-o k$, -ök alakja vált irodalmivá, ezért használja Vass József ezt a változatot. A harmadik esetben szintén a birtokos személyrag két különböző alakjával találkozunk. Az $-a,-e$ magánhangzók az ómagyar korban egyedül jelölték az egy birtokot, később a magánhangzóra végződő szavak esetén ejtéskönnyitő hangként betoldták a $-j$ mássalhangzót. Végül állandósult a $-j a,-j e$ alak és megjelent a mássalhangzóra végzödö szavak esetén is. A V2-ben megjelenő alak arra enged következtetni, hogy a norma csak a XIX. században alakult ki, amikor a magyar nyelv helyesírását egységesítették. ${ }^{189}$

Valószínü, hogy Vass József a korabeli helyesíráshoz alakította a jelentés szövegét, ez megfigyelhető a hónapok, napok elnevezésénél, valamint egyes helyneveknél.

V1: Kis Asszony havában, sz Márton napjára, Érsek-Újvár.

V2: kisasszony-havában, szentmárton napjára, Érsekújvár.

Egyes esetekben a mondathatár, vagy a szórend nem egyezik meg.

V1: "Nemkülönben $n$ gróf Cancellárius Kálnoki Sámuel urnak két diáriuma, egyik rendes könyvben, másik egy kalendáriom tiszta leveleire irva, ez a két utolsó ujadon új találmány, méltóztassanak Excellencziátok ö Nagyságától kinyerni."

V2: "Nemkülönben(...) egyik rendes könyvben, másik egy kalendáriom tiszta leveleire irva. Ez a két utolsó ujadon új találmány. Méltóztassanak Excellencziátok ö Nagyságától kinyerni." 190

V1: ismét serkenteni fogom

V2: ismét fogom serkenteni

A közölt változat néhány latin szó esetén magyar kiejtés szerinti írásmódot használ, szemben a kéziratbeli latin szóval: arcusból - árkusból, ecclesia - eklézsia, vagy latin szót ad meg olyan helyen, ahol a kézirat magyart használ: összeg - summa, nyugtatványomat quientantiámat.

Ezek a változatok azonban még nem zavarják meg a szöveg értelmét. A felsorolt müvek címeinek esetén sokkal következetesebb és helyesebb az Uj Magyar Muzeumban közölt változat, a másoló ugyanis több esetben kis kezdöbetủvel írja a mü címét.

-V1: Andrea Scharsii ordinata digestio status Saxo - Ecclesiastici in Trannia

\footnotetext{
${ }^{186}$ Aranka György jelentése. 9.

${ }^{187}$ Vass $1854,409$.

${ }^{188}$ Lásd bövebben: Bárczi-Benkő-Berrár, 400.

${ }^{189} \mathrm{Az}$ első akadémiai szabályzat megjelenésének éve 1832.

${ }^{190}$ I.m. 408.
} 
- Schmeizel compendium historiae civilis et Ecclesiasticae Tranniae

- Martini Schmeizel collegium in historiam ad statum regni Hungariae

- Xilander historia Motuum Bocskaianor

Az Új Magyar Muzeumban ez így jelenik meg :

V2: Andrea Scharsii : Ordinata digestio status Saxo - Ecclesiastici in Trannia

- Schmeizel : Compendium historiae civilis et Ecclesiasticae Tranniae

- Martini Schmeizel : Collegium in historiam ad statum regni Hungariae

- Xilander : Historia motuum Bocskainorum

Vass József meglehetösen szabadon kezeli a szöveget, ugyanis egy teljes bekezdést elhagy amelyben Aranka a vele történt szerencsétlenséget meséli el -. majd később, amikor Aranka balesetére hivatkozva mentegetőzik, betold egy magyarázó mondatot: „ugyanis Jakabfalván egy kutya lábát veszélyesen megmarta."191 A jelentés végén is elhagyja a hagyományos záróformulát, amely a kéziratban így hangzik: „vagyok Excellencziátoknak és a mlgs fö Tanácsnak alázatos szolgája ", az az Új Magyar Muzeum-ban csak ennyi: "vagyok stb."

Nyilvánvaló, hogy a beiktatott változtatásokat a kiadás ténye, az újabb helyesírási rendszer, a közérthetöség tette szükségessé. Erre a korra ugyanis már kialakult egy egységes magyar irodalmi nyelv, melyet az 1832-es helyesírási szabályzat hitelesített. A szöveg ilyen mértékben való megváltoztatása számos kérdést vet fel. Az elsỏ a kiadói jog kérdése: mennyire szabad a kiadónak a szöveget megmásitani, és saját belátása szerint átírni. Vass József közlése végülis posztumusz kiadás, de ó nem jelöli meg a jelentés lelöhelyét. A közlést azzal indokolja, hogy egy évvel korábban megjelent Brúz Lajos közlésében Benkö József cikke Erdély kiadatlan magyar történetírói címmel ${ }^{192}$-ö tehát csak hozzáad. Meg szeretné írni a két társaság részletes történetét, ez tehát egyféle elözetes lenne a késöbbi munkához. ${ }^{193}$

Feltevödik a kérdés, hogy melyik verziót tekinthetjuk hitelesnek. Ez esetben nem csak az szól a Mák Ferenc másolta szöveg elsöbbsége mellett. hogy kézirat, és hogy két évvel korábban keletkezett, hanem a fent bemutatott tartalmi eltérések is. Feltételezhetjük azt is, hogy Vass verziója az eredeti, Aranka által írt jelentést használta fel, mégis inkább az képezheti vita tárgyát, hogy mennyire jogos a kézirattal való ilyenszerú bánásmód, mennyire van joga a kiadónak hozzátoldani, elvenni belöle, igazitani rajta. Ha úgy tekintjük, hogy Vass célja az ismertetés volt - saját bevallása szerint mint szaktanár, mint erdélyi érzi magát felhatalmazva az adatok közlésére ${ }^{194}-$, akkor jogos volt néhány változtatás.

\subsection{Müfaji szempontú vizsgálat}

A kézirat nyilvánvalóan jelentés, $\mathrm{s}$ mint ilyen, az okirat-irodalomhoz tartozik. Vannak azonban a szövegnek olyan elemei, melyek áttörik a dokumentum-irodalom által megengedett hivatalos és merev határokat és az útleírảs müfajához vezetnek. Ezeket szeretném bövebben kifejteni, úgy, hogy elöször a jelentẻsre jellemző szövegelelmeket, alakzatokat vizsgálom meg, majd azokat, amelyek az útleírásra utalnak. Elsỏ esetben inkább formai jegyckröl van szó, a másodikban inkább tartalmiakról. A vizsgảlatot Révai Miklós $A$ magyar szép toll ${ }^{193}$ címủ munkája alapján végzem, mivel ez a mủ a jelentés keletkezésẻnek korában született, a benne levő elöirások a korabeli elvárásokat tükrözik. Aranka nem

\footnotetext{
${ }^{191}$ uo.

${ }^{192}$ Lásd: Új Magyar Muzeum 1853 V. fuzet, 217-239.

${ }^{193}$ Vass $1854,402$.

194 I.m. 401.

${ }^{195}$ Éder (s.a.r) 1973
} 
olvashatta Révai mủvét, aki Johann Christoph Adelung 1785-ben Berlinben megjelent munkáját fordítja le és dolgozza át, melynek címe: Über den deutschen Styl. Arankának valószínüleg nem volt szüksége modellre a jelentés megírásához, foglalkozásánál fogva naponta találkozott ezzel a mủfajjal, az összevetést azért tartom helyénvalónak, mert Révai műve az elmélet, Arankáé pedig a gyakorlat felöl világítja meg a jelentés mủfaját.

Révai a mủ második részében értekezik a középszerü tollról - latinul stylus mediocris.

„Annak egyenes tzéljai ezek: hogy vagy a' polgári életnek foglalatoskodásiról szólljon, vagy az értelemnek történt igaz esetekról tudományt adjon, vagy pedig azt némely valóságok felöl is meggyözze. Egyik tzélját sem érheti el az író, ha a' dolgokat úgy nem adja elö, a' mint valósággal vagynak.

A középszerü tollnak három neme van: foglalatoskodó, történeti és tanító toll, a foglalatoskodó toll a magán- és köz- foglalatosságokról szól, az utóbbinak két alfaja van: stylus curalis és stylus cancellariae. Megítélésem szerint Aranka jelentése az utóbbihoz tartozik. A meghatározás után Révai felsorolja a stílus jellemzöit, ezeket most egyenkẻnt szeretném összevetni a kézirat szövegével.

„A hibátlanság, tisztaság, világosság itt is oly szükséges, mint akármelyik más tollban"

- mondja Révai, ${ }^{197}$ majd így folytatja:

„....a' méltóságot, 's tettben valóságot nagy mértékben megkivánja, mely minden alatsonyt, barátságost, más e félét, egy általjảban kizár. "90

Aranka szövegére valóban jellemző a méltóság és valóság, azonban egyes esetekben az alacsony is szerepel, a jelentés hangneme ugyanis néhol személyes, például, amikor a balesetről vagy az útleirás kiadásáról beszél.

Egy másik kitétel, hogy „... fökẻppen szükséges a világosság, s értelemesség, a szoros meghatározással", ezenkívül a „velös rövidséget, s általjában szóllást" ${ }^{\text {91 }}$ emeli ki Révai. Aranka írása megfelel ezeknek, ugyanis rendszerességgel, sorba szedve közli az információkat, helyszíneket, kőnyvcímeket.

Révai szerint fontos a tiszteletadás:

„Mivel a személyeknek egymásra való tekintetök, az öszveszerződött, és olly igen egybekötelözött polgári társaságban olly különbözó, s a méltóság és tisztelet megkivánja ezen tekintetnek szóval adott jelenségét [...] E pedig föképpen a tzimekben áll."

Aranka szövegében nagyon jól végigkövethetjưk a címek és rangok jelenlétét már a megszólítástól kezdve: „Nagyméltóságú Főkormányzó Úr, Méltóságos Főtanảcs, Kegyelmes és kegyes jó Méltóságos Uraim." A kézirat gyakran használja az "Excellencziátok" megszólítást, ha valakit említ, mindig a név elé teszi az illető rangját is: $t$. dr. Pataki, mélt.

\footnotetext{
${ }^{196}$ I.m. 199.

${ }^{197}$ i.m. 204.

${ }^{90}$ i.m. 205.

${ }^{91}$ i.m. 206.

92 i.m. 207.
} 
gr. Haller Sigmondné, vagy mélt. püspök úr ő excellecziája. Ezenkívúl az igehasználat is: „méltóztassanak bölcsen végezni, s rendelni ez iránt”, „bátorkodom alázatosan jelenteni” kifejezi a tisztelet megadását.

A másik szempont, hogy ezt a szöveget nem csak egyszerü jelentésnek tekintjuk. Bár nagyon lakonikus, mégis egy megtett utazás leírása. Az útleírás müfajához áll legközelebb, mely a tapasztalatok tárgyszerü rögzítésére összpontosít. Nem útleírás a szó szoros értelmében, de egyes elemei erre utalnak. Az első részben hosszabban kifejti Köpecen való tartózkodását, elmondja szerencsétlen balesetét, amely miatt célját nem valósíthatta meg. Leginkább a szöveg végén megjelölt utolsó cél bemutatása érdemel figyelmet. Aranka ugyanis egy útleírást tervez,

„, hogy a hazafiaknak egy jó példát, jó elméknek pedig csekély igyekezetemmel egy üj ösztönt adjak."

Tudatosan példának állítja jövendöbeli írását, a Nyelvmívelö Társaság programjához híven szeretné szűkebb pátriáját megismerni és ismertetni.

Aranka nemcsak tudományos céllal utazik, nemcsak nyelvápoló, de néprajzkutató és természetbúvár is:

„,nem vontam meg a figyelmemet a szántás-vetéstöl, fonástól és más mesterségektől, azokat a tárgyakat, mellyek a természet esméretit (:naturalis historiat:) illetik mindenütt [...] megnéztem."

Arankát tehát céltudatosság és valóban tudósi magatartás jellemzi, nemcsak mellékesen figyel a haza ,polgári és más állapotjaira”, hanem megosztott figyelemmel járja végig a székely székeket. Nemcsak megnézi az Almási barlangot, a Bálványos várát és a Büdös hegyét, de a hegységek „terméseiböl” el is hoz gyüjteménye számára.

\section{A jelentés egybevetése a Kéziratkiadó és a Nyelvmívelö Társaság programjával}

Aranka első alkalommal a Kéziratkiadó Társaság megbízásából utazott, hogy kéziratokat gyújtsön, az összegyüjtött anyagból 1796-ban Szebenben adott ki a Nyelvmívelö Társaság egy antológiát. ${ }^{93}$ Ebben jelent meg „Az erdélyi Kéz-Irásban lévő Történet-Iróknak ujjabb bővebb Laistroma"94 és „Lajos Királly Vitézeinek Énekek a' Mohátsi szerentsétlen ütközet elött", 95 melyet Jakabfalván talált Kovács Dánielnél.

A kőzölt lajstrom a már 1791-ben megjelent elsö verzió bỏvített vảltozata, a székelyföldi utazás valamint egy 1794-es magyarországi út után Aranka szükségesnek tartotta a bỏvítést. A jelentésben említett munkák közül a következök jelennek meg a lajstromban (a címeket a kéziratban való elöfordulásuk sorrendjében közlöm, feltüntetve az esetleges különbségeket):

- Boytinus de rebus gestis Gabrielis Bethlen libri 3 in fol. Deákul

- Rákóczi Ferenc levelezései 1704-től 1711-ig - ez a lajstromban a következő formában szerepel: 1706 - 1709 Rákoczi Ferentz Frantzia Levelezés

\footnotetext{
${ }^{93} M N y T, 1796$

94 i.m. 178-205.

95 i.m. 254-256.
} 
- Bethlen János históriája

- Csiki Cserei Mihály jegyző könyve 1631 - 1658 - a lajstromban év nélkül

- Haller Gábor diáriuma 1629 -tỏl 1643-ig - a lajstromban az évszám 1629 - 1644

- Kálnoki István diáriuma 1644 - a lajstromban az évszám 1645

- Rhédei László diáriuma 1653 - 1657 - a lajstromban év nélkül

- Kemény János: Ruina exercitus Trannici - a lajstromban a következő cím jelenik meg: Apologia seu ruina Exercitus Transilvanici

- Vizaknai Briccius diáriuma 1703 - 1712 - a lajstromban az évszám 1703 - 1715

Dálnoki Veress Gerzson kuruc világról írt versei

- Egri Fodor Sámuel diáriuma, I. Apaffi Mihálynak Érsekújvár alá menetelérỏl, ott léte s hazajöveteléről - a lajstromban: Egri Fodor Sámuel diáriuma 1633

- Xilander história Motuum Bocskaianor 1604 -1606 - a lajstromban szerző és év nélkül

- N.P. Lakatos Siculiája - a lajstromban Joh. Lakatos Siculia

- Mikó Ferenc históriája, Bíró Sámuel ugyanakkori folytatásának toldalékával

- Mósa László Erdély Diplomatica Históriája 1686 - 1743 - a lajstromban év nélkül

A továbbiakban egyenként szeretném összevetni a kẻziratban Aranka által felsorolt célokat a Kéziratkiadó és Nyelmívelö Társaság programjával. Bảr Aranka a Kéziratkiadó Társasảg megbizásából utazott, még a Nyelvmivelö Társaság megalakulása elött, ${ }^{96}$ ủgy gondolom, helyénvaló az összevetés az utóbbi programjával is, mivel már 1791 -ben megírta mindkét tervezetet. Tehát figyelhetett olyan dolgokra is, melyeket a Nyelvmívelö Társaság Rajzolata tartalmazott.

Az utazás elsődleges célja a kéziratok felkutatása:

„...elsó célt ezt tettem föl magamnak: hogy ha mi a k.k.irások társasága tárgyára szükséges kézirások a székely földén még hevernének, azokat felkeressem."

Aranka nem határozza meg a kéziratok milyenségét, mủfajảt, csak azt tudjuk meg, hogy a Társaság tárgyára szükségesek. A Kéziratkiadó Társaságról felállított Rajzolatban így ír erröl Aranka:

„...nemes hazánk és nagyérdemü eleink viselt dolgainak kézirásban heverö $s$ veszedelemben forgó, kérdésben levó darabjai [...] ki mondhatatlan nagy károkkal hevernek a porban nyomtalanul, és azoknak kiadások mind arra nézve igen szükséges, mind az egész világ elött igen becsületes, s e mostani idö-szakasznak örökös megdiszitésére szolgáló dolog légyen."

A Nyelvmivelő Társaságról szóló elmélkedésben Aranka külön fejezetet ír Hazánk esméreté-röl, ${ }^{98}$ itt sem tudjuk meg pontosan a könyvek jellegét. Az utazás eredménye, hogy talál történelmi tárgyú munkát, naplót, verseket, okiratgyunjteményt, és müfajtól függetlenül hoz magával olyan kéziratokat, amelyeket megfelelőnek talál, a nyomda minőségi munkálatainak igazolására pedig két imádságos könyvet is elhoz.

Második és „mellesleg való” célként említi a Marosszék tisztségeinek számbavételét. Egy, már meglévő kéziratot kell kiadásra előkészitenie, kidolgoznia. A munka ,a lajstromban az 1505-dik esztendő szám alatt" van, valószínü a korábban - 1791-ben -összeállított kéziratlistáról beszél Aranka. A kézirat nemek és ágak különbségét tartalmazza,

\footnotetext{
${ }^{96}$ Aranka 1793 szeptemberében utazott, a Nyelvmívelő Társaság 1793 december 3-án tartotta alakuló gyülését

97 Jancsó, 1955, 102

${ }^{98}$ Arnka, 179l b. 28.
} 
tehát egyfajta sematizmus lehet, melyhez a szükséges „,világosítást” kell mellékelni. Aranka olyan filológiai munkát vállal, melynek célja a szöveg és olvasó közti - nemcsak idöbeli távolság áthidalása, a jobb, könnyebb megértés. A Kéziratkiadó Társaság felállításáról szóló Rajzolat-ban igy ír erről Aranka:

„a munkák [...] minek elötte nyomtató sajtó alá adatnának, azelött mindenfelöl összeszereztetvén vagy kiírattatván azok amint a 4-dik pont alatt le vagyon írva, mind az írásbeli hibáktól tisztittatnának meg, mind pedig a dologra nézve szükséges jegyzésekkel dolgoztatnának ki. S végre igy adatván sajtó alá, jó papirosra, szép betükkel és csinosan úgy nyomtattatnának ki.",99

Aranka nemcsak a szerkesztői, hanem a nyomdai tevékenységre is figyel. Szintén erre a területre tartozik a harmadik cél: a kiadás érdekébenm szeretné megtalálni a Kászonszék eredetét bizonyító iratot. A dokumentum - Aranka bevallása szerint - szintén a lajstromban szerepel, és kiadásra szeretné elökészíteni. Egyik esetben sem járt szerencsével. Talált ugyan iratokat, de maga az eredeti gróf Lázár Istvánnál volt, ezért kérte a Tanácsot, hogy maguk keressék meg Lázár Istvánt az irat ügyében.

A negyedik célja egyéni érdekủ - saját okirat - és könyvgyüjteményét szeretné bővíteni. Ezzel együtt említi azon igyekezetét, hogy a társaságnak újabb tagokat toborozzon. A tagság bővítése mindkét társaság tervezetében megtalálható:

$$
\text { „Jelentkezzék, ki e nemes szándéknak támogatója akar lenni. ",00 }
$$

Söt egy propagáló tartalmú levelet is szétküld Aranka. ${ }^{101}$

Valóban fontos volt a tagok toborzása. Aranka elképzelése szerint a vidéki szerzők is fontosak voltak, sỏt a kéziratgyüjtés esetén éppen a vidéken élő tagok szolgálhattak meglepetéssel - egy-egy új és ritka kézirattal, szöveggel.

Utolsó célként említi egy útleírás elkészítését. Erre vonatkozóan egyik tervezetében sem találunk konkrét információkat. Saját bevallása szerint példát akar adni. Figyelemre méltó ez a gondolat, ugyanis az utazások virágkorát éljük. Számos magyar utazó megy külföldre tanulni, világot látni, vagy egyszerủen kedvtelésből. A magyar utazók nagy részét azonban még mindig az idegen tájak, népek vonzzák, Aranka pedig Erdély fele fordul.

Miután felsorolja az általa megtekintett helyeket és megfigyelt jelenségeket, azután válik világossá, hogy a Hazánk esmérete címủ fejezet ${ }^{102}$ szinte minden alpontját megtaláljuk itt: régi pénzek, könyvek, földben talált nagy állatok csontjai, ércek, kövek, fảk nevei, időjárás, termés. ${ }^{103}$ Mindarra figyel, amit egy korabeli utazó fontosnak tart, csakhogy ő nem a külföld, hanem saját szủkebb pátriảja felé fordul. Az útleírását magyarul szeretné kiadni, egy olyan korban, mikor a nyomtatványok nagy része még mindig latin nyelven jelenik meg. Nem kívülről és más nemzetektől kell megismernünk hazánkat, hanem éppen azoknak kell tölünk „leckét és utasítást" venni. Ezek az elvek nemcsak a tudományosságot, konkrétan a honismeretet kívánják szolgálni, hanem a nyelvmủvelést és nemzeti öntudatot is támogatják. Fel akarja hívni a figyelmet a haza értékeire és tudatosítani a majdani olvasóban ezeket az értékeket. Összevetve a második, 1797-es utazással, ${ }^{104}$ amelynek célja szintén a

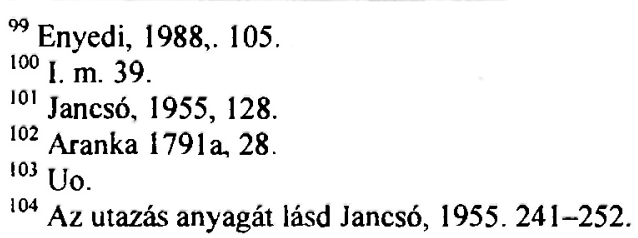


Székelyföld bejárása volt, azonban a Nyelvmívelö Társaság megbízásából, megállapithatjuk, hogy nagyon sok közös pontja van a két utazásnak, Aranka számos olyan helyre ellátogat, ahol 1794-ben is járt, Csíksomlyón több napig is elidöz. Azonban ezúttal nem elsődleges célja a könyvek, kéziratok felkutatása. A megfigyelések nagy része a biológia, földrajz, növénytan, egészségügy területére tartozik: például Szovátán bö a bükkmakk termése, kártékonykodik a pele, Parajdon a Fekete-várban mozaikpadlózatot találtak, Hídvégen gróf Nemess Ferencnél „,muszka herbatéj"-re talált, levéböl és magvából hozott a titoknok. Ez alkalommal is legtöbb könyvet Benkö Józseftöl valamint a csíksomlyói konventbỏl hozta el. ${ }^{105}$ Valószinü, hogy 1797-es útja alkalmával is toborzott tagokat a Társaságnak, szinte minden helységböl megnevez olyan személyeket, akik „a Társasághoz való hajlandóságot“ mutatnak vagy pénzbeli támogatást igérnek. Sok esetben a tagoknak a Nyelvmívelö Társaság munkáinak elsö darabját küldik el a meghívólevél mellett. Ebben a beszámolóban is - akárcsak a jelentésben -, kiemelt helyre kerül a csíksomlyói nyomda és könyvtár. Mivel az utazás anyaga két gyủlés jegyzőkönyvében maradt fenn, a bejelentett megfigyelés, jelenség után rögtön megjelenik a jövőre vonatkozó intézkedés, terv. Így bepillantást nyerhetünk a Nyelvmívelö Társaság munkásságába, tevékenységének jellegébe, módszereibe. A felsorolásból úgy tünik, hogy a második út alkalmával Aranka sokkal több természetismereti jellegü megfigyelést gyüjtött össze. A jelentésben ugyanis egy pár név felsorolása után kijelenti, hogy a természetismereti megfigyelések nem ide tartoznak.

Mindkét utazás révén olyan méretü anyagot és információt gyüjtött, amely felbecsülhetetlen értéket jelentett a Társaságnak, vannak olyan felfedezések, amelyek a mai tudományosság szemszögéböl naivnak tủnnek, de születtek hamisitások is, például annak a szerecsendió-pohárnak az esete, amelyet 1412-re datáltak. ${ }^{106}$ Aranka személye és tevékenysége fogta össze a két társaságot, ö azonban 1798-ban lemondott a titoknokságról, többek között ez is hozzájárult ahhoz, hogy egyre ritkábban tartottak gyüléseket, majd 1806ban megszünt a Társaság. ${ }^{107}$

\section{8. Összegzés}

Az általam vizsgált Aranka - szöveg csak töredéke egy hatalmas szövegkorpusznak, mégis sok vizsgálati lehetöséget nyújt. Lehetetlen azonban a szöveg által kínált minden irányt követni és kimeríteni. Dolgozatom súlypontjait a szövegfeltárảs, a müfaji kérdések vizsgálata és ezáltal az Aranka szövegkorpusz bövítése képezte. A szöveget összevetettem az Új Magyar Muzeumban 1854-ben publikált verzióval, hogy rávilágitsak a kézirat és kiadás közötti különbségekre, ez a hitelesség kérdését vetette fel. Megvizsgáltam a szöveget müfaji szempontból, mivel úgy gondolom a jelentés szükszavủ „ủtleírảs“" is. Ezutản Aranka céljait és a Kéziratkiadó valamint Nyelvmívelö Társaság tervezetét állitottam egymás mellé, és a talált munkák további sorsát próbáltam nyomon követni. Végül röviden egybevetettem a két utazás anyagát, sủlypontjait és eredményeit, mindezt azonban a rangsorolás igẻnye nélkül. Ezért számos kérdés marad még nyitva a további kutatás számára, ilyen például a jelentésben említett, de a Nyelvmivelö Társaság által kiadott gyüjteményben megjelent lajstromból hiányzó múvek holléte, további sorsa, az Aranka ảltal igért útleírás megvalósulásának kérdése (nem tudunk róla semmi bizonyosat). Talảlhatók a kéziratban olyan nevek, amelyekröl nem találtam megbízható adatokat, vannak mủvek, amelyek szerzöje ismeretlen. Mindezek ellenére a jelentés értékes és érdekes darabja az Aranka

\footnotetext{
${ }^{105}$ Uo.

${ }^{106}$ Bövebben lásd Jancsó 1955, 250.

${ }^{107}$ I.m. 69-73.
} 
szöveghagyománynak, vizsgálata pedig tanulságos, mert számos olyan információt tartalmaz, amely eddig figyelmen kívưl maradt, elötérbe helyezi az utazás fogalmát és Arankát mint utazót. Aranka olyan helyekre, intézményekre mutat rá - például a csíksomlyói nyomdára -- amelyekröl körében kevesen vagy keveset tudtak, olyan kéziratokat, történelmi és szépirodalmi munkákat gyűjt össze, amelyek komoly értékkel bírnak. 